\title{
Effects of past climate variability on fire and vegetation in the cerrãdo savanna of the Huanchaca Mesetta, NE Bolivia
}

\author{
S. Y. Maezumi ${ }^{1,2,5}$, M. J. Power ${ }^{1,2}$, F. E. Mayle ${ }^{3}$, K. K. McLauchlan ${ }^{4}$, and J. Iriarte ${ }^{5}$ \\ ${ }^{1}$ Department of Geography, University of Utah, 260 S. Central Campus Dr., Rm: 270, Salt Lake City, UT 84112, USA \\ ${ }^{2}$ Natural History Museum of Utah, 301 Wakara Way, Salt Lake City, UT 84103, USA \\ ${ }^{3}$ Department of Geography and Environmental Science, Centre for Past Climate Change, University of Reading, \\ Whiteknights, P.O. Box 227, Reading RG6, UK \\ ${ }^{4}$ Department of Geography, Kansas State University, 118 Seaton Hall, Manhattan, KS 66506, USA \\ ${ }^{5}$ Department of Archaeology, College of Humanities, University of Exeter, Laver Building, North Park Road, \\ Exeter EX4 4QE, UK
}

Correspondence to: S. Y. Maezumi (shira.maezumi@gmail.com)

Received: 14 November 2014 - Published in Clim. Past Discuss.: 30 January 2015

Revised: 29 March 2015 - Accepted: 15 April 2015 - Published: 8 June 2015

\begin{abstract}
Cerrãdo savannas have the greatest fire activity of all major global land-cover types and play a significant role in the global carbon cycle. During the 21 st century, temperatures are projected to increase by $\sim 3{ }^{\circ} \mathrm{C}$ coupled with a precipitation decrease of $\sim 20 \%$. Although these conditions could potentially intensify drought stress, it is unknown how that might alter vegetation composition and fire regimes. To assess how Neotropical savannas responded to past climate changes, a 14500 -year, high-resolution, sedimentary record from Huanchaca Mesetta, a palm swamp located in the cerrãdo savanna in northeastern Bolivia, was analyzed with phytoliths, stable isotopes, and charcoal. A nonanalogue, cold-adapted vegetation community dominated the Lateglacial-early Holocene period (14 500-9000 cal yr BP, which included trees and $\mathrm{C}_{3}$ Pooideae and $\mathrm{C}_{4}$ Panicoideae grasses. The Lateglacial vegetation was fire-sensitive and fire activity during this period was low, likely responding to fuel availability and limitation. Although similar vegetation characterized the early Holocene, the warming conditions associated with the onset of the Holocene led to an initial increase in fire activity. Huanchaca Mesetta became increasingly firedependent during the middle Holocene with the expansion of $\mathrm{C}_{4}$ fire-adapted grasses. However, as warm, dry conditions, characterized by increased length and severity of the dry season, continued, fuel availability decreased. The establishment of the modern palm swamp vegetation occurred at 5000 cal yr BP. Edaphic factors are the first-order control on
\end{abstract}

vegetation on the rocky quartzite mesetta. Where soils are sufficiently thick, climate is the second-order control of vegetation on the mesetta. The presence of the modern palm swamp is attributed to two factors: (1) increased precipitation that increased water table levels and (2) decreased frequency and duration of surazos (cold wind incursions from Patagonia) leading to increased temperature minima. Natural (soil, climate, fire) drivers rather than anthropogenic drivers control the vegetation and fire activity at Huanchaca Mesetta. Thus the cerrãdo savanna ecosystem of the Huanchaca Plateau has exhibited ecosystem resilience to major climatic changes in both temperature and precipitation since the Lateglacial period.

\section{Introduction}

The cerrãdo savanna of central South America is the largest, richest, and likely most threatened savanna in the world (DaSilva Meneses and Bates, 2002) The cerrãdo is the second largest biome in South America, covering $1.86 \times 10^{6} \mathrm{~km}^{2}$ and is home to over 10000 plant species (Myers et al., 2000). The tropical forest-savanna ecotones within the cerrãdo biome are of considerable interest to biologists because of their high habitat heterogeneity (beta diversity), importance in rainforest speciation (Russell-Smith et al., 1997) and sensitivity to climate change (IPCC, 2014). 
According to current estimates, however, only $20 \%$ of the cerrãdo remains undisturbed and only $1.2 \%$ of the area is preserved in protected areas (Mittermeier et al., 1999). Additionally, cerrãdo savannas have a significant role in the modern global carbon cycle because of high $\mathrm{CO}_{2}$ loss associated with frequent natural fire activity (Malhi et al., 2002). Currently savanna fires are considered the largest source of natural pyrogenic emissions, with the most fire activity of all major global land-cover types (Pereira, 2003). In the last few decades, deforestation for agriculture and increased drought have resulted in increased burning in savannas, contributing to approximately $12 \%$ of the annual increase in atmospheric carbon (Van der Werf et al., 2010).

The cerrãdo biome comprises forest, savanna, and campestre (open-field) formations (Abreu et al., 2012; Mistry, 1998). Cerrãdo sensu stricto is characterized as a woody savanna formation composed of dense, thin, and rocky outcrops with cerrãdo physiognomies that are distinguishable based on their densities, heights, and scattered tree-shrub covers with roughly $50 \%$ trees and $50 \%$ grass (Abreu et al., 2012). The principal determinants of the growth and development of the cerrãdo vegetation types are largely related to edaphic factors (Colgan et al., 2012). For example, the distribution of major cerrãdo vegetation types is closely related to the geomorphology of the Precambrian Brazilian Shield in South America (Killeen, 1998a). The development of the variety of cerrãdo vegetation communities is largely the result of the heterogeneous nature of the edaphic features (Killeen, 1998a) including the depth of the water table, drainage, the effective depth of the soil profile, the presence of concretions (Haridasan, 2000), soil texture, and the percentage of exposed rock (Junior and Haridasan, 2005).

In addition to edaphic constraints, climate also has a prominent role in determining cerrãdo savanna vegetation structure and fire activity (Ribeiro and Walter, 2008). The cerrãdo biome is dominated by a warm, wet-dry climate associated with the seasonal migration of the Intertropical Convergence Zone (ITCZ) (DaSilva Meneses and Bates, 2002; Latrubesse et al., 2012; Vuille et al., 2012). On synoptic climatological timescales, temperature and precipitation are the most important effects of climate on fire (e.g., months to seasons to years) (Mistry, 1998). These factors govern net primary productivity (NPP) and the abundance of available fuels (Brown and Power, 2013; Marlon et al., 2013). Warmer temperatures are typically associated with increased burning through vegetation productivity and the occurrence of firepromoting climatic conditions. However, the role of temperature can be mediated by precipitation (Brown and Power, 2013). Fire responds differently to increases in precipitation depending on whether fuel is initially abundant or limited in the ecosystem (Marlon et al., 2013; Mistry, 1998). In arid and semi-arid environments, such as the cerrãdo, increases in precipitation tend to increase fire, whereas increased precipitation in humid environments can reduce fire (Marlon et al., 2008, 2013).
The seasonality of the precipitation coupled with abundant wet-season lightning ignitions (Ramos-Neto and Pivello, 2000) is linked to high fire frequency in the cerrãdo (Miranda et al., 2009). Wet-season lightning fires typically start in open vegetation (wet fields or grassy savannas), with significantly higher incidence of fire in more open savanna vegetation (Ramos-Neto and Pivello, 2000). High biomass production during the wet season results in abundant dry fuels favoring frequent fires throughout the year (Ramos-Neto and Pivello, 2000). Data show a positive correlation with fine fuel build-up and both fire temperature and fire intensity (energy output) (Fidelis et al., 2010). Thus, increased wet-season fuel accumulation in the cerrãdo increases fire intensity. Based on an ecosystems adaptation to fire it can be classified as independent, fire-sensitive, and fire-dependent (Hardesty et al., 2005). In fire-independent ecosystems such as tundra and deserts, fire is rare, either because of unsuitable climate conditions or lack of biomass to burn. Fire-sensitive ecosystems such as tropical rainforests are damaged by fire, which disrupts ecological processes that have not evolved with fire (Hardesty et al., 2005). Fire-dependent systems such as the well-drained grasslands of the cerrãdo biome have evolved in the presence of periodic or episodic fires and depend on fire to maintain their ecological processes (Hardesty et al., 2005). Fire-dependent vegetation is fire-adapted, flammable, and fire-maintained (Miranda et al., 2009; Pivello, 2011).

The study of fire and vegetation change in the cerrãdo is increasingly important as population, agricultural activity, and global warming create pressing management challenges to preserve these biodiverse ecosystems (Mistry, 1998). The long-term role of humans on vegetation and fire regimes of the cerrãdo remains unclear. There is increasing evidence for a late Holocene (3000 cal yr BP) increase in Mauritia flexuosa (M. flexuosa) and fire activity in Bolivia, Colombia, Venezuela, and Brazil, which has been attributed to both natural and anthropogenic drivers (Behling and Hooghiemstra, 1999; Berrio et al., 2002a; DaSilva Meneses et al., 2013; Kahn and de Castro, 1985; Kahn, 1987, 1988; Montoya and Rull, 2011; Rull, 2009).

To investigate the drivers of vegetation and fire in the cerrãdo, a long-term perspective is needed. The past few decades have experienced increased global temperatures, increased atmospheric $\mathrm{CO}_{2}$, and unprecedented levels of deforestation (Malhi et al., 2002). These recent changes heavily influence modern ecological studies, thus limiting the understanding of the role of natural variability in these systems. Long-term paleoecological studies can provide baseline information on processes shaping forest-savanna firevegetation dynamics from centennial to millennial timescales (Mayle and Whitney, 2012). These long-term studies can inform whether recent shifts in ecotones are the result of a minor short-term oscillation around a relatively stable ecotone or a longer-term (e.g., millennial scale) unidirectional ecotonal shift forced by climate change (Mayle et al., 2000; Mayle and Whitney, 2012). Additionally, long-term paleoe- 
cological records help form realistic conservation goals and identify fire management strategies for the maintenance or restoration of a desired biological state (Willis et al., 2007).

In this study, the long-term paleoecological perspective provides a context for understanding the role of centennial to millennial climate variability in the evolution of fire and vegetation in cerrãdo savanna ecosystems. The purpose of this research is to explore long-term environmental change of cerrãdo savanna palm swamps in Bolivia from the Lateglacial (ca. $15000 \mathrm{cal} \mathrm{yr} \mathrm{BP)} \mathrm{to} \mathrm{present.} \mathrm{Paleoecological} \mathrm{proxies} \mathrm{in-}$ cluding lithology, magnetic susceptibility, loss on ignition (LOI), charcoal, stable isotope, and phytolith data are used to investigate long-term ecosystem processes in the cerrãdo savanna. There are three primary hypotheses investigated in this study:

1. Edaphic conditions are the dominant control on the presence of savanna versus forest vegetation on the Huanchaca Mesetta.

2. Climate is the dominant control on savanna structure and floristic composition.

3. The late Holocene rise in M. flexuosa was driven by climate rather than a change in human land use.

\subsection{Study site}

Noel Kempff Mercado National Park (NKMNP), a $15230 \mathrm{~km}^{2}$ biological reserve in northeastern Bolivia, is located on the Precambrian Brazilian Shield near the southwestern margin of the Amazon Basin, adjacent to the Brazilian states of Rondônia and Mato Grosso (Burbridge et al., 2004). It is a UNESCO World Heritage Site, in recognition of its globally important biodiversity and largely undisturbed ecosystems, including terra firme (non-flooded) evergreen rainforest, riparian and seasonally flooded humid evergreen forest, seasonally flooded savanna, wetlands, upland cerrãdo savannas, and semi-deciduous dry forests (Mayle et al., 2007). NKMNP occupies an ecotone between Amazon rainforest to the north and dry forests and savannas to the south, containing 22 plant communities (Fig. 1) (Burn et al., 2010). Huanchaca Mesetta palm swamp (14 $32^{\prime} 10.66^{\prime \prime} \mathrm{S}$, $60^{\circ} 43^{\prime} 55.92^{\prime \prime} \mathrm{W}$; elevation: $1070 \mathrm{~m}$ a.s.1.) is located within NKMNP on the Huanchaca Mesetta - an 800-900 m elevation table mountain. The palm swamp is approximately 200 by $50 \mathrm{~m}$, comprised entirely of a monospecific stand of the palm M. flexuosa.

\subsection{Climate}

The climate of NKMNP is characterized by a tropical wet and dry climate (DaSilva Meneses and Bates, 2002). The mean annual precipitation at NKMNP derived from nearby weather stations (Concepción, Magdalena, San Ignacio) is ca. $1400-1500 \mathrm{~mm}$ per year, with mean annual temperatures between 25 and $26^{\circ} \mathrm{C}$ (Hanagarth, 1993; Montes de Oca, 1982; Roche and Rocha, 1985). There is a 3- to 5-month dry season during the Southern Hemisphere winter (May to September-October), when the mean monthly precipitation is less than $30 \mathrm{~mm}$ (Killeen, 1990). Precipitation falls mainly during the austral summer (December to March), originating from a combination of deep-cell convective activity in the Amazon Basin from the South American summer monsoon (SASM) and the ITCZ (Vuille et al., 2012). The SASM transports Atlantic moisture into the basin and corresponds to the southern extension of the ITCZ. The ITCZ is driven by seasonal variation in insolation; thus, maximum Southern Hemisphere insolation and precipitation occur in the austral summer (Bush and Silman, 2004; Vuille et al., 2012). During winter (June, July, August), cold, dry polar advections from Patagonia, locally known as surazos, can cause shortterm cold temperatures to frequently decrease down to $10^{\circ} \mathrm{C}$ for several days at a time (Latrubesse et al., 2012; Mayle and Whitney, 2012). These abrupt decreases in temperature may potentially influence the distribution of temperature-limited species on the Huanchaca Mesetta.

\subsection{Geomorphology}

The Huanchaca Mesetta table mountain is near the western limit of the Precambrian Brazilian Shield and dominates the eastern half of NKMNP. It is composed of Precambrian sandstone and quartzite (Litherland and Power, 1989). The top of the mesetta is flat, with a gently rolling surface and at elevations ranging from 500 to $900 \mathrm{~m}$ above sea level (a.s.l.) (DaSilva Meneses and Bates, 2002). The substrate of the mesetta is rocky, and soils are thin and low in organic material (Litherland and Power, 1989). Continuity of the crystalline or sedimentary blocks of the mesetta is broken by an extensive network of peripheral or inter-mesetta depressions formed from a combination of erosion, dolerite dike intrusions, and faulting on the mesetta (DaSilva Meneses and Bates, 2002; Litherland and Power, 1989). These depressions act as catchments for sediment and water, resulting in sediment accumulation, which supports more complex vegetation communities. High species diversity exhibited on the Huanchaca Mesetta, compared with other savanna regions of South America, is attributed to the long history of isolation of this edaphically controlled table-mountain savanna (Mayle et al., 2007).

\subsection{Vegetation}

The cerrãdo savanna on Huanchaca Mesetta is dominated by a continuous grass cover with sparsely scattered small trees and shrubs that grows on the thin, well-drained, nutrient-poor soils (Killeen, 1998b). Woody species include Byrsonima coccolobifolia, Caryocar brasiliensis, Erythroxylum suberosum, Vochysia haenkeana, and Callisthene fasciculata. Trees and shrubs include Qualea multiflora, Emmotum nitens, Myr- 


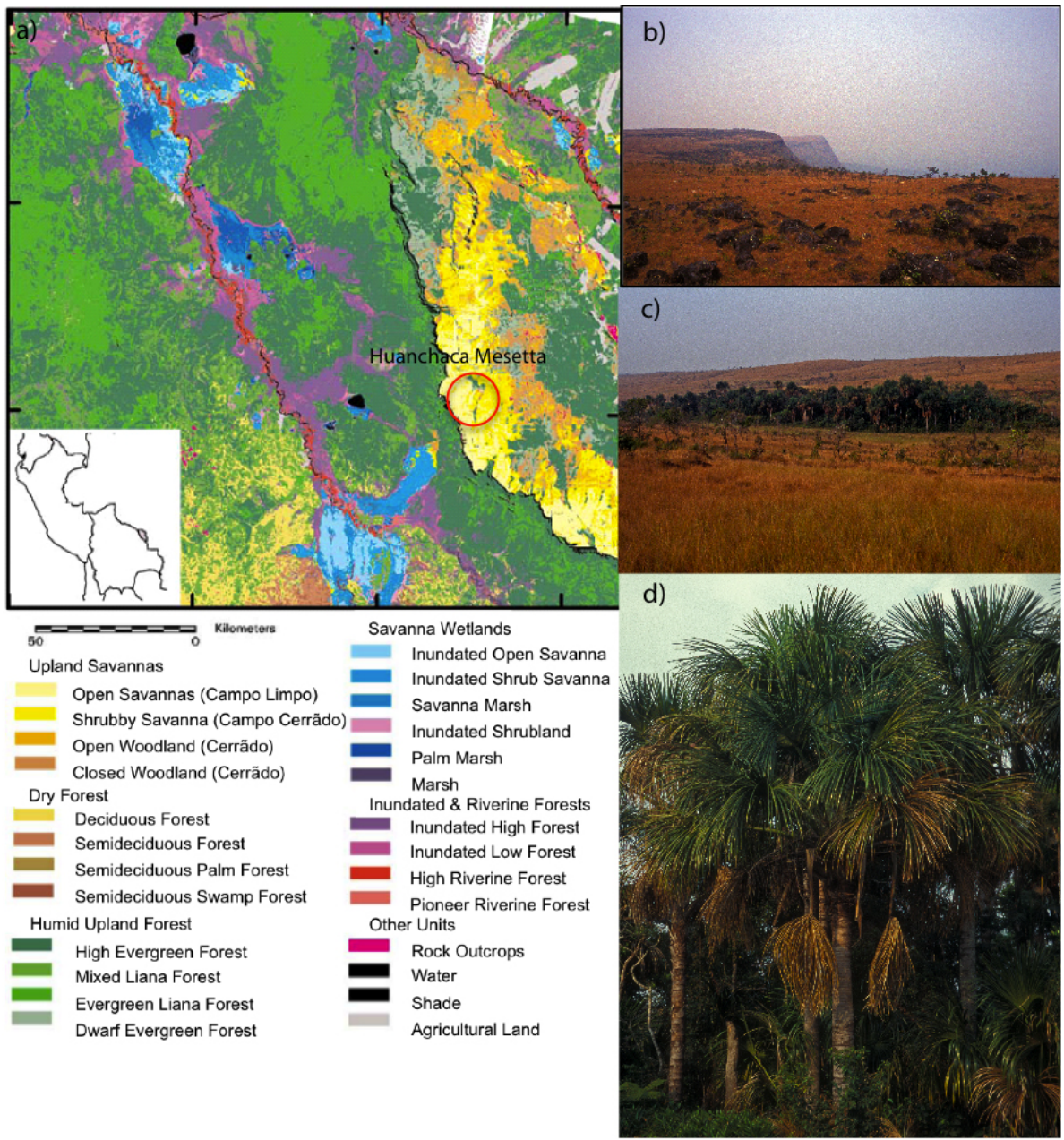

Figure 1. Huanchaca Mesetta study site (a) vegetation map of Noel Kempff Mercado National Park (NKMNP) modified from Killeen (1998b), (b) view from atop Huanchaca Mesetta, (c) Huanchaca Mesetta palm swamp, and (d) monospecific stand of Mauritia flexuosa. Photos by F. Mayle.

cia amazonica, Pouteria ramiflora, Diptychandra aurantiaca, Kielmeyera coriacea, Ouratea spectabilis, and Alibertia edulis. Small shrubs include Eugenia punicifolia and Senna velutina, and herbaceous species include Chamaecrista desvauxii and Borreria sp. Monocot families include the Rapateaceae $\left(\mathrm{C}_{3}\right)$ (Cephalostemon microglochin), Orchidaceae (Cleistes paranaensis) $\left(\mathrm{CAM}, \mathrm{C}_{3}\right)$, Iridaceae (Sisyrinchium spp.) $\left(\mathrm{C}_{4}\right)$, Xyridaceae (Xyris spp.) $\left(\mathrm{C}_{4}\right)$, and Eriocaulaceae (Eriocaulon spp., Paepalanthus spp., Syngonanthus spp.) $\left(\mathrm{C}_{4}\right)$ (Killeen, 1998b). In the interfluvial depressions organic-rich soil is sufficiently deep to support humid evergreen forest islands, which are typically dominated by monospecific stands of M. flexuosa (DaSilva Meneses and Bates, 2002; Mayle and Whitney, 2012). M. flexuosa is a monocaulous, arborescent palm, averaging $20-30 \mathrm{~m}$ tall which is typically associated with a low, dense understory (da Silva and Bates, 2002; Furley and Ratter, 1988; Kahn, 1988). M. flexuosa is confined to lower elevations (<ca.
$1000 \mathrm{~m}$ elevation) in warm/wet climates (Rull and Montoya, 2014). M. flexuosa swamps favor interfluvial depressions that remain flooded during the dry season, when the surrounding terrains dry out (Huber, 1995a, b; Kahn and de Granville, 1992). The abundance of M. flexuosa in permanently flooded, poorly drained soils is the result of pneumatophores (aerial roots), which enable its growth in anaerobic conditions (Kahn, 1988; Rull and Montoya, 2014). Seasonal water deficits saturate the soil profile in the wet season and desiccate soil during the dry season, resulting in a dominance of herbaceous versus woody plants surrounding the interfluvial depressions (Killeen, 1998b). The seasonal dryness leads to drought, plant water stress, and frequent fire activity, resulting in the development of xeromorphic and sclerophyllous plant characteristics on the open mesetta (Killeen, 1998b). The spatial distribution of evergreen forest versus drought-tolerant savanna vegetation is additionally constrained by edaphic conditions, limiting the expan- 
sion of forest vegetation because of the heavily weathered sandstone soils dominant outside the interfluvial depressions (Killeen and Schulenberg, 1998). Limited soil development precludes rainforest from developing on the large, rocky expanses of the mesetta (Killeen and Schulenberg, 1998). The essentially treeless campo cerrãdo that grows around Huanchaca Mesetta palm swamp is edaphically constrained and has likely grown on this mesetta for millions of years (Mayle and Whitney, 2012). Thus, the vegetation of the Huanchaca Mesetta is influenced by both climatic and non-climatic controls including seasonal hydrologic conditions, edaphic soil constraints, and frequent fire activity (Killeen and Schulenberg, 1998).

\section{Materials and methods}

\subsection{Sediment core}

A $5.48 \mathrm{~m}$ long sediment core from Huanchaca Mesetta palm swamp was collected in 1995 using a Livingstone modified square-rod piston corer from the center of the swamp. The uppermost $15 \mathrm{~cm}$, containing a dense root mat, was discarded because of the presence of fibrous roots and potential for sediment mixing. Huanchaca Mesetta sediment cores were transported to the Utah Museum of Natural History for analysis. They were photographed and described using a Munsell soil color chart. Visual descriptions, including sediment type, structure, texture, and organic content, were undertaken to assist interpretation of the paleoenvironmental data.

\subsection{Chronology}

The chronological framework for Huanchaca Mesetta was based on eight accelerator mass spectrometry (AMS) radiocarbon dates from non-calcareous bulk sediment and wood macrofossils analyzed at the University of Georgia Center for Applied Isotope Studies (Table 1). The uncalibrated radiometric ages are given in radiocarbon years before AD 1950 (years before "present", yr BP). Radiocarbon ages were calibrated using CALIB 7.0 and the IntCal13 calibration data set (Reimer et al., 2013). IntCal13 was selected in place of the SHcal13 calibration curve because of the latitudinal location $\left(14^{\circ} \mathrm{S}\right)$ of Huanchaca Mesetta and the proximal hydrologic connection with the origin of the South American monsoon in the Northern Hemisphere. The seasonal migration of the ITCZ is thought to introduce a Northern Hemisphere ${ }^{14} \mathrm{C}$ signal to the low-latitude Southern Hemisphere (McCormac et al., 2004). This study area is located in the low latitudes $\left(14^{\circ} \mathrm{S}\right)$ and within the range of the ITCZ migration; thus, the IntCal13 calibration curve was selected for the radiocarbon calibrations. Following calibration, the mean age value of calibrated years before present (cal yr BP) of the largest probability at $2 \sigma$ standard deviation was used to reflect both statistical and experimental errors) (grey bars in Fig. 2). These mean ages were used to create the smooth-

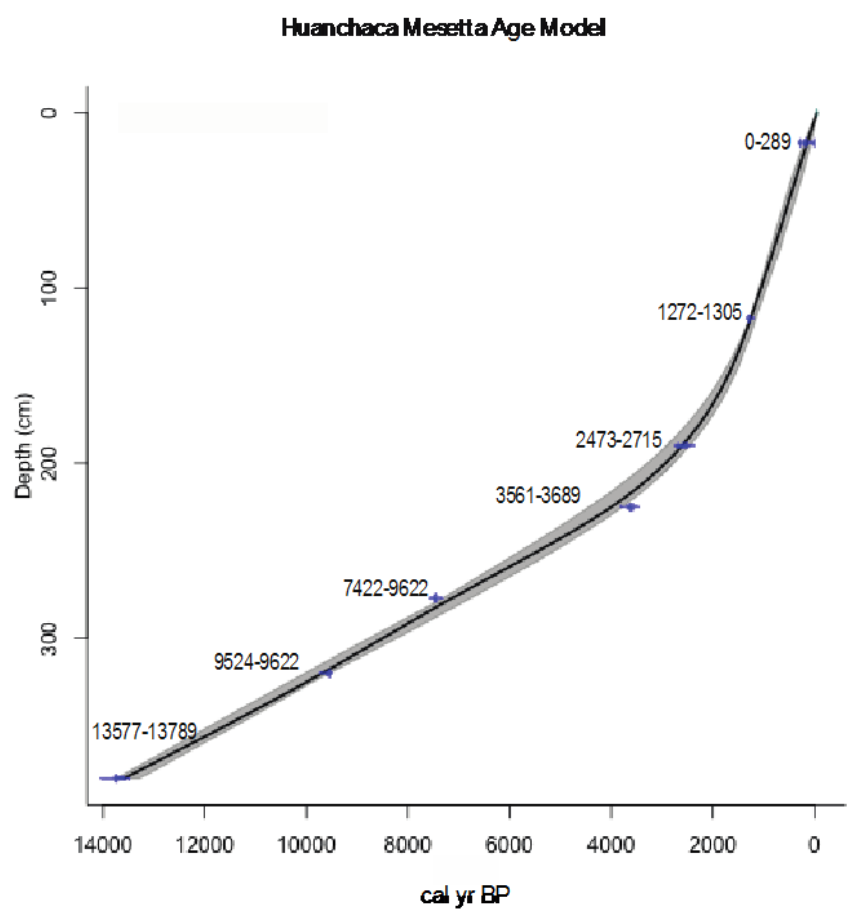

Figure 2. CLAM age-depth model for Huanchaca Mesetta. Grey bars represent $2 \sigma$ error.

ing spline age model using classical age-depth modeling in the package CLAM (Blaauw, 2010) within the open-source statistical software R.

\subsection{Loss on ignition}

The variability in the organic and carbonate content of sediments is used, in conjunction with magnetic susceptibility, to identify periods of variability in sediment composition and organic content throughout the Holocene. Organic and carbonate sediment composition was determined by loss on ignition (LOI), conducted at contiguous $1 \mathrm{~cm}$ increments throughout the cores. For each sample, $1 \mathrm{~cm}^{3}$ of sediment was dried in an oven at $100^{\circ} \mathrm{C}$ for $24 \mathrm{~h}$. The samples underwent a series of $2 \mathrm{~h}$ burns in a muffle furnace at 550 and $1000^{\circ} \mathrm{C}$ to determine the relative percentage of the sample composed of organics and carbonates. Concentration was determined by weight following standard methodology (Dean Jr., 1974).

\subsection{Magnetic susceptibility}

Magnetic susceptibility (MS) was measured to identify mineralogical variation in the sediments (Nowaczyk, 2001). The MS of sediments is reflective of the relative concentration of ferromagnetic (high positive MS), paramagnetic (low positive MS), and diamagnetic (weak negative MS) minerals or materials. Typically, sediment derived from freshly eroded rock has a relatively high MS, whereas sediments that are 
Table 1. AMS radiocarbon dates from Huanchaca Mesetta.

\begin{tabular}{llrrrr}
\hline Lab number & Material & $\begin{array}{r}\text { Depth } \\
(\mathrm{cm})\end{array}$ & $\begin{array}{r}{ }^{14} \mathrm{C} \text { age } \\
(\mathrm{yr} \mathrm{BP})\end{array}$ & $\begin{array}{r}\delta^{13} \mathrm{C} \\
\text { ratio }\end{array}$ & $\begin{array}{r}\text { IntCal13 2 } \sigma \\
(\text { cal year BP })\end{array}$ \\
\hline UGAMS 15158 & Macrofossil & 17 & $190 \pm 20$ & -28.8 & $0-289$ \\
UGAMS 17252 & Bulk sediment & 58 & $2310 \pm 25$ & -18.8 & $2211-2356$ \\
UGAMS 15264 & Bulk sediment & 118 & $1360 \pm 20$ & -22.9 & $1272-1305$ \\
UGAMS 12023 & Bulk sediment & 190 & $2480 \pm 20$ & -22.62 & $2473-2715$ \\
UGAMS 17253 & Bulk sediment & 225 & $3365 \pm 25$ & -20.7 & $3561-3689$ \\
UGAMS 17254 & Bulk sediment & 277 & $6545 \pm 30$ & -22.6 & $7422-9622$ \\
UGAMS 15159 & Bulk sediment & 320 & $8600 \pm 30$ & -22.8 & $9524-9622$ \\
UGAMS 17255 & Bulk sediment & 380 & $11905 \pm 35$ & -16.3 & $13577-13789$ \\
\hline
\end{tabular}

dominated by organic debris, evaporites, or sediments that have undergone significant diagenetic alteration typically have a low or even negative MS (Reynolds et al., 2001). Shifts in the magnetic signature of the sediment can be diagnostic of a disturbance event (Gedye et al., 2000). Sediment cores were scanned horizontally, end to end, through the ring sensor.

MS was conducted at $1 \mathrm{~cm}$ intervals using a Barington ring sensor with a $75 \mathrm{~mm}$ aperture.

\subsection{Charcoal}

Sediment samples were analyzed for charcoal pieces greater than $125 \mu \mathrm{m}$ using a modified macroscopic sieving method (Whitlock and Larsen, 2001) to reconstruct the history of local and extra-local fires. Charcoal was analyzed in contiguous $0.5 \mathrm{~cm}$ intervals for the entire length of the sediment core at $1 \mathrm{~cm}^{3}$ volume. Samples were treated with $5 \%$ potassium hydroxide in a hot water bath for $15 \mathrm{~min}$. The residue was gently sieved through a $125 \mu \mathrm{m}$ sieve. Macroscopic charcoal (particles $>125 \mu \mathrm{m}$ in minimum diameter) was counted in a gridded Petri dish at $40 \times$ magnification on a dissecting microscope. Non-arboreal charcoal was characterized by two morphotypes: (1) cellular "graminoid" (thin rectangular pieces; one cell layer thick with pores and visible vessels and cell wall separations) and (2) fibrous (collections or bundles of this filamentous charcoal clumped together). Arboreal charcoal was characterized by three morphotypes: (1) dark (opaque, thick, solid, geometric in shape, some luster, and straight edges), (2) lattice (cross-hatched, forming rectangular ladder-like structure with spaces between), and (3) branched (dendroidal, generally cylindrical with successively smaller jutting arms) (Jensen et al., 2007; Mueller et al., 2014; Tweiten et al., 2009). Charcoal pieces were grouped into non-arboreal and arboreal categories based on their morphology, which enabled the characterization of fuel sources in the charcoal record (Mueller et al., 2014).

Charcoal counts were converted to charcoal influx (number of charcoal particles per cubic centimeter) and charcoal influx rates by dividing by the deposition time $\left(\mathrm{yr} \mathrm{cm}^{-1}\right)$ using CharAnalysis statistical software (Higuera et al., 2009).
In CharAnalysis, charcoal data were decomposed to distinguish background charcoal from distinct charcoal peaks based on a standard methodology to calculate a set of threshold criteria (Higuera et al., 2007). The background threshold was calculated using a 700-year moving average. If the charcoal data exceed that background threshold, the charcoal peak is interpreted as a fire episode.

\subsection{Stable isotopes}

Stable carbon isotopes were analyzed as an additional proxy for changes in vegetation structure and composition. Carbon isotopic composition of terrestrial organic matter is determined primarily by the photosynthetic pathway of vegetation (Malamud-Roam et al., 2006). Previous research on $\delta^{13} \mathrm{C}$ values of the Huanchaca Mesetta have been used to determine the relative proportions of $\mathrm{C}_{4}$ savanna grasses versus $\mathrm{C}_{3}$ woody and herbaceous vegetation (Killeen et al., 2003; Mayle et al., 2007).

Sediment $\delta^{15} \mathrm{~N}$ integrates a variety of nutrient cycling processes including the loss of inorganic $\mathrm{N}$ to the atmosphere through denitrification (McLauchlan et al., 2013; Robinson, 1991). Denitrification and the subsequent enrichment of $\delta^{15} \mathrm{~N}$ requires abundant available carbon, available nitrate, and anaerobic conditions (Seitzinger et al., 2006). Thus, wet, anoxic soils tend to have enriched values of $\delta^{15} \mathrm{~N}$. Environmental conditions that alter from wet (anaerobic) to dry (aerobic) conditions also enrich $\delta^{15} \mathrm{~N}$ values (Codron et al., 2005). During dry periods, denitrification is shut off because of an increase in available oxygen in sediments, and thus $\delta^{15} \mathrm{~N}$ values decrease. If dry soils become hydrated, there is a preferential loss of ${ }^{14} \mathrm{~N}$, enriching $\delta^{15} \mathrm{~N}$ values (Codron et al., 2005). Stable isotope analysis was conducted at $3 \mathrm{~cm}$ resolution for total carbon $(\mathrm{C})$ and nitrogen $(\mathrm{N})$ throughout the length of the sediment core. One cubic centimeter of bulk sediment was dried, powdered, and treated with $0.5 \mathrm{M}$ hydrochloric acid to remove carbonates. A range of $1-25 \mathrm{mg}$ of the dried carbonate-free sediment was weighed into tin capsules depending on organic matter content. The samples were analyzed on a Finnigan Delta dual-inlet elemental analyzer at the Sirfer Lab at the University of Utah. ${ }^{13} \mathrm{C} /{ }^{12} \mathrm{C}$ 
and ${ }^{15} \mathrm{~N} /{ }^{14} \mathrm{~N}$ ratios are presented in delta $(\delta)$ notation, in $\%$ (\%o relative to the PDB and $\mathrm{N}_{2}$ air standards) (Codron et al., 2005).

\subsection{Phytoliths}

Phytoliths preserve well in sediment records and are especially useful in areas with intermittent dry periods. Phytoliths were used as a proxy to reconstruct past vegetation composition and are especially useful in the lower taxonomic identification of grasses (Piperno and Pearsall, 1998). Grass phytoliths can provide important paleoecological information. Tropical $\mathrm{C}_{4}$ grasses, adapted to open environments with high seasonality of rainfall, typically expand at the expense of $\mathrm{C}_{3}$ grasses and other tropical forest species during drier intervals (Hartley and Slater, 1960; Hartley, 1958a, b; Piperno, 1997). $C_{4}$ Panicoideae grasses are generally adapted to warm moist conditions, whereas $\mathrm{C}_{4}$ Chlorideae grasses are adapted to warm, dry conditions (Hartley and Slater, 1960). $C_{3}$ subfamilies, including the Pooideae, are adapted to cool and moist conditions, and are currently confined to temperate climates with lower temperatures (Hartley, 1961, 1973; Iriarte, 2006). The presence of $C_{3}$ Pooideae grasses from phytolith data from southeastern Pampas grasslands in Uruguay have been interpreted to indicate a shorter dry season with overall conditions that were cooler than during the Holocene (Iriarte, 2006). Phytolith samples were taken every $4 \mathrm{~cm}$ along the sediment core. The extraction and slide preparation of phytoliths were conducted at the University of Exeter, UK, following standard procedures described by Piperno (2005). Slides were scanned and counted at the University of Utah Power Paleoecology Lab using a Leica EMED compound light microscope $(400-1000 \times)$. The number of phytoliths counted varied from 101 to 320 per slide. The modern palm swamp is a monospecific stand of $M$. flexuosa that produces globular echinate phytoliths but does not produce hat-shaped phytoliths characteristic of other Arecaceae (Piperno, 2005). Although other palms produce globular echinate phytoliths, the current monospecific stand supports the identification of globular echinate phytoliths as belonging to this palm.

Given the abundance of $M$. flexuosa during the middle and late Holocene, phytolith percentages from globular echinate phytoliths were calculated separately. Percentages of nonMauritia phytoliths were calculated on the basis of the total sum of phytoliths excluding M. flexuosa. Phytolith identification was made by comparison with modern plant reference collections curated at the University of Exeter Archaeobotany Lab. The classification of Poaceae implemented a three-partite morphological classification related to grass taxonomy (Panicoideae-Chloridoideae-Pooideae) (Twiss et al., 1969) and further developed in both North America (Fredlund and Tieszen, 1994) and the Neotropics (Bertoli de Pomar, 1971; Iriarte and Paz, 2009; Iriarte, 2003; Piperno and Pearsall, 1998; Piperno, 2005; Sendulsky and Labouriau, 1966; Söndahl and Labouriau, 1970; Teixeira da Silva and
Labouriau, 1970; Zucol, 1999, 2000, 1996, 1998). The phytolith percentage diagrams were plotted using Tilia and Tilia*Graph software (Grimm, 1987). CONISS was used to calculate phytolith zones (Grimm, 1987). CONISS is based on cluster analysis, with the constrain that clusters are formed by hierarchical agglomeration of stratigraphically adjacent samples to minimize dispersion within the clusters (Bennett, 1996; Grimm, 1987). The divisions were chosen using a broken-stick model to determine the number of statistically significant zones at the lowest dispersion within the clusters (Bennett, 1996).

\section{Results}

Five distinct zones were identified, i.e. zone 1, the Lateglacial (14500-11800 cal yr BP); zone 2, the early Holocene (11800-9000 cal yr BP); zone 3 , the middle Holocene (8000-3500 cal yr BP); and zone 4 and zone 5, the late Holocene ( 3500 cal yr BP to present).

\section{Zone 1: $14500-11800$ cal yr BP: Lateglacial}

The Lateglacial vegetation on Huanchaca Mesetta was dominated by arboreal taxa, grasses, and Asteraceae (opaque perforated platelets) phytoliths (Fig. 3). The phytolith assemblage likely contains both in situ vegetation production and wind-blown vegetation from the surrounding rocky savanna. Both $\mathrm{C}_{4}$ Panicoideae and $\mathrm{C}_{3}$ Pooideae grass phytoliths were present during the Lateglacial. The presence of $\mathrm{C}_{3}$ Pooideae grasses is interpreted as the result of cooler Lateglacial conditions compared to present. The Lateglacial vegetation community at Huanchaca Mesetta lacks a modern analogue plant community in NKMNP. The presence of both $\mathrm{C}_{3}$ Pooideae and $\mathrm{C}_{4}$ Panicoideae grasses suggest some degree of landscape heterogeneity. A consistent layer of very dark sandy silt dominated the lithology of Huanchaca Mesetta during the Lateglacial. The magnetic susceptibility and bulk density values were low and exhibit minimum variability compared to the rest of the record (Fig. 4). Coupled with LOI organic values below $10 \%$, the sediment lithology was summarized as a low-energy depositional environment with relatively low nutrient input. Organic matter deposited during the Lateglacial had $\delta^{13} \mathrm{C}$ values of $-16 \%$ (Fig. 5), indicating a contribution of $\mathrm{C}_{4}$ grasses to organic matter composition. The proportion of $\mathrm{C}_{3}$ to $\mathrm{C}_{4}$ grass contribution was calculated by using values of $\mathrm{C}_{3}$ and $\mathrm{C}_{4}$ grasses and a simple two-pool mixing model (Perdue and Koprivnjak, 2007) with end-member values of $-27 \%$ o for $\mathrm{C}_{3}$ and $-12 \%$ o for $\mathrm{C}_{4}$ plants. The contribution of $\mathrm{C}_{4}$ vegetation was ca. $80 \%$, higher than any other time in the Huanchaca record. Modern $\delta^{13} \mathrm{C}$ values in the basin range from -18 to $-22 \%$. The location of these $\mathrm{C}_{4}$ droughtadapted grasses was likely the surrounding plateau. Organic carbon concentrations gradually increased from 1 to $4 \%$ during the Lateglacial, indicating relatively low amounts of organic matter in the system compared to those of today. The 


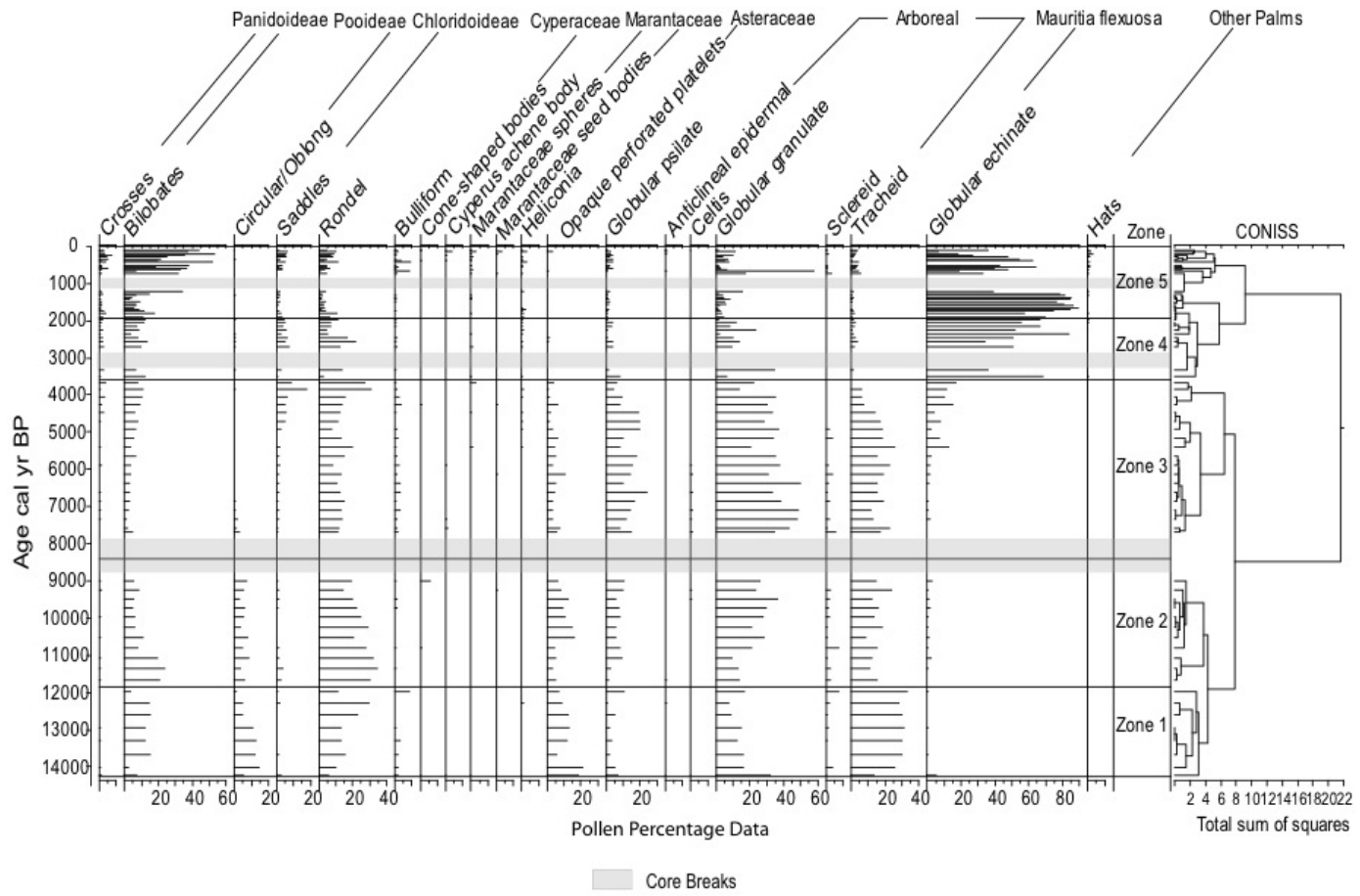

Figure 3. Huanchaca Mesetta phytolith data separated by zones created by constrained cluster analysis (CONISS). Grey bars indicate core breaks.

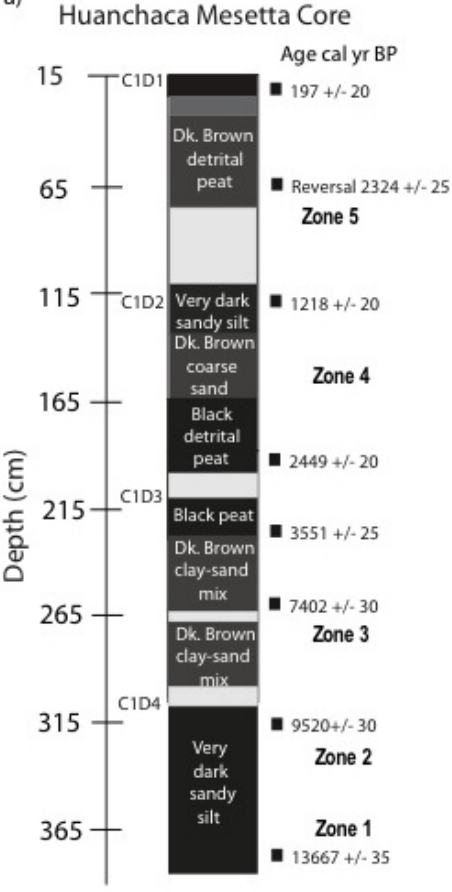

b) Magnetic Susceptibility c) LOI Organics d) Bulk Density

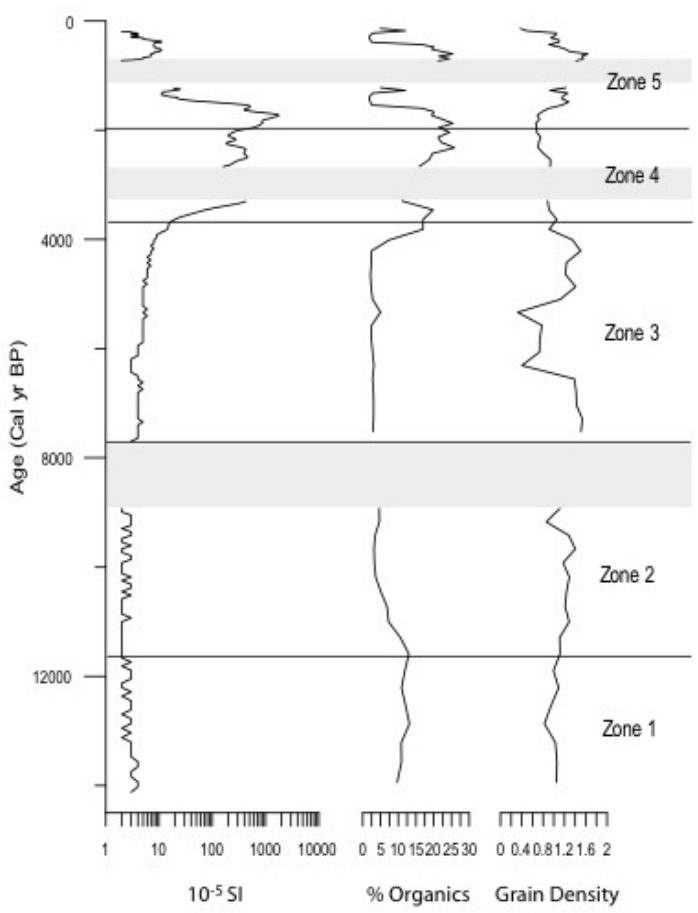

Core Breaks

Figure 4. Huanchaca Mesetta lithology: (a) lithological description of the core profile, (b) magnetic susceptibility, (c) loss on ignition (LOI), and (d) bulk density. Zones derived from phytolith data. Grey bars represent core breaks. 


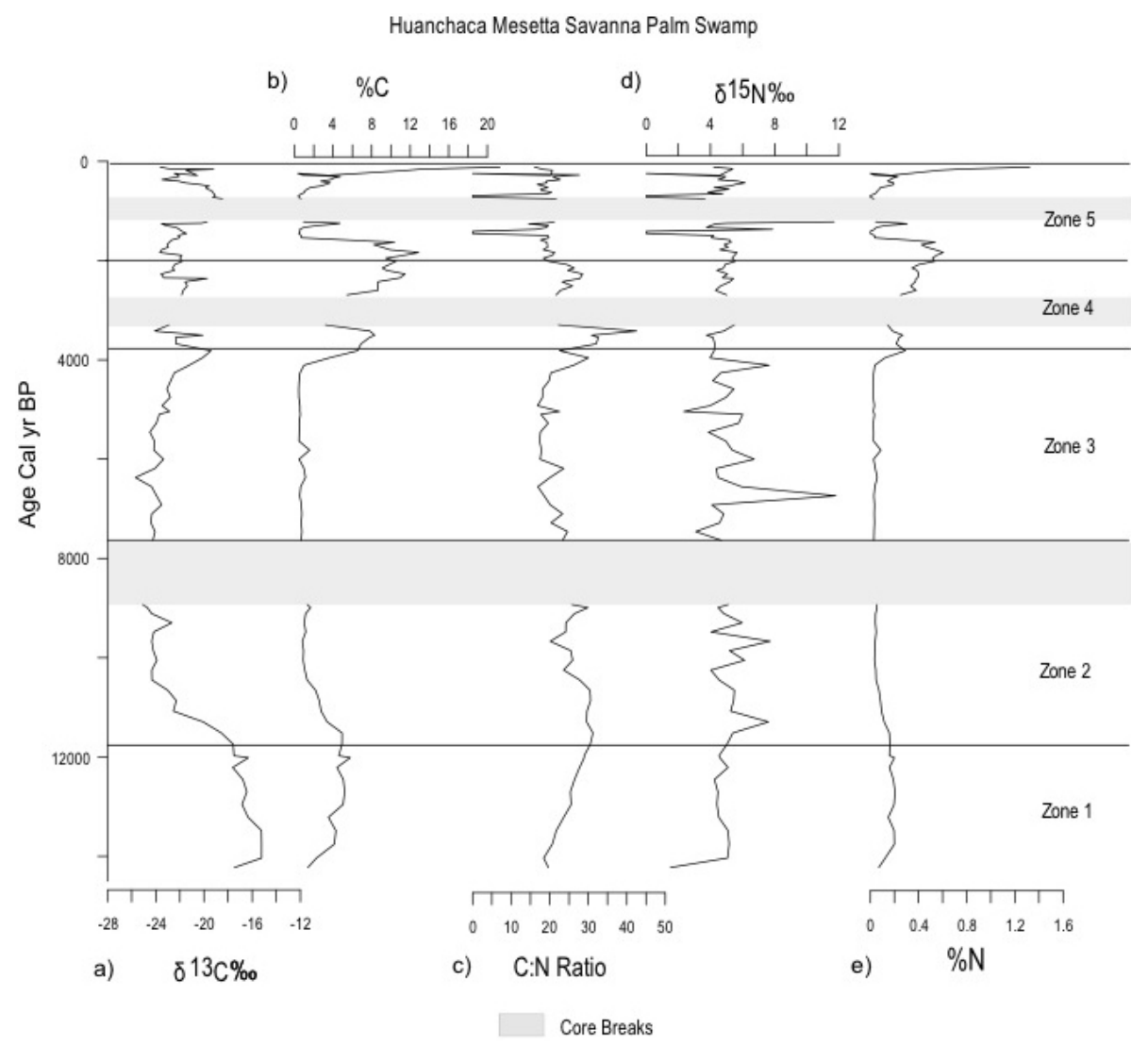

Figure 5. Huanchaca Mesetta stable isotope data: (a) $\delta 13 \mathrm{C}$, (b) $\%$ total carbon, (c) carbon to nitrogen ratio, (d) $\delta^{15} \mathrm{~N}$, and (e) $\%$ total $\mathrm{N}$. Zones derived from phytolith data. Grey bars indicate core breaks.

$\mathrm{C}: \mathrm{N}$ ratio ranged from 20 to 30 , indicating a terrestrial organic matter source. $\mathrm{N}$ concentrations were low, from 0.1 to $0.2 \%$, and the $\delta^{15} \mathrm{~N}$ values were ca. $5 \%$, indicating minimal denitrification during the Lateglacial. The $\delta^{13} \mathrm{C}, \% \mathrm{C}_{4}$ contribution, and high $\mathrm{C}: \mathrm{N}$ values coupled with the phytolith data dominated by trees and grasses suggest a predominantly terrestrial signal characterized by an open savanna grassland during the Lateglacial (Fig. 6). The $\delta^{15} \mathrm{~N}$ values suggest that sediments within the swamp were drier than present creating aerobic conditions and low denitrification rates.

Charcoal influx levels were low during the Lateglacial (14 500-12 000 cal yr BP). The fire return interval (FRI) was two fire episodes per 1000 years (Fig. 7). Based on the $0.5 \mathrm{~cm}$ sampling resolution of this record, fire "episodes" were interpreted as periods of increased fire activity rather than isolated fire "event". The charcoal signature was consistent with frequent, low intensity fires that likely occurred in the open, grass-dominated mesetta surrounding the basin. Low charcoal influx levels coupled with low-magnitude charcoal peaks suggest that the non-analogue vegetation structure of $\mathrm{C}_{3}$ Pooideae, $\mathrm{C}_{4}$ Panicoideae, and arboreal phytoliths likely created a fuel structure that lacked sufficient density or fuel connectivity to produce abundant arboreal or grass charcoal. Low charcoal influx coupled with low fire frequency sug- gest that the Lateglacial environment was likely fire-sensitive within the basin.

\section{Zone 2: 11 800-9000 cal yr BP: early Holocene}

There were decreased $\mathrm{C}_{4}$ Panicoideae grasses, with consistent levels of $\mathrm{C}_{3}$ Pooideae grasses, arboreal, and Asteraceae (opaque perforated platelets) phytoliths. The presence of $\mathrm{C}_{3}$ grasses, and the absence of $M$. flexuosa, the dominant component of the modern basin vegetation, suggest temperatures cooler than present. The lithology, magnetic susceptibility, bulk density, and LOI values indicate minimal shift during the vegetation transition. Organic geochemistry reflected a change in organic matter source, with $\delta^{13} \mathrm{C}$ values becoming more negative, indicating an increase in the contribution of $\mathrm{C}_{3}$ vegetation at ca. $11000 \mathrm{cal} \mathrm{yr} \mathrm{BP}$. The $\delta^{13} \mathrm{C}$ contribution of $\mathrm{C}_{4}$ grasses decreased dramatically from 60 to $20 \%$ during this period (Fig. 8). These data correspond to a decrease in $\mathrm{C}_{4}$ Panicoideae grass phytoliths and an increase in arboreal phytoliths. Low levels of terrestrial organic input into the system were indicated by low carbon concentrations and $\mathrm{C}: \mathrm{N}$ values ranging between 25 and $30 . \mathrm{N}$ cycling changed during the time of this zone, with $\delta^{15} \mathrm{~N}$ values exhibiting greater amplitude and higher frequency variability. 


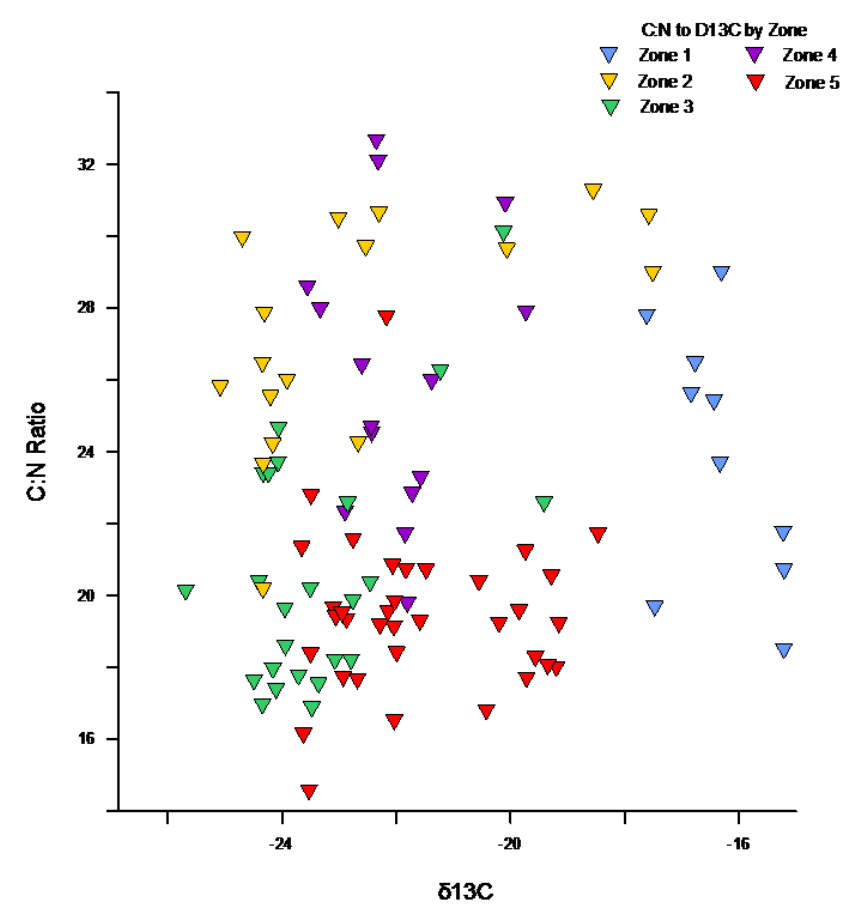

Figure 6. $\mathrm{C}: \mathrm{N}$ ratio to $\delta^{13} \mathrm{C}$ stable isotopes by zones determined from phytolith data.

The $\delta^{15} \mathrm{~N}$ values ranged between 4 and $8 \%$, indicating increased variability in denitrification rates associated with increasing wet (anaerobic) to dry (aerobic) conditions. The $\mathrm{N}$ concentrations were low, between 0.05 and $0.01 \%$, indicating minimal nitrogen availability in the system.

Charcoal influx at Huanchaca Mesetta increased at ca. 11200 cal yr BP coupled with an increase in the fire frequency to five episodes (periods of increased burning) per 1000 years. The peak magnitude values indicated two substantial fire episodes (periods of increased burning) at ca. 10200 and $9100 \mathrm{cal}$ yr BP. The lack of significant change in the lithology suggests that taphonomic conditions were consistent during this interval. The increase in grass phytoliths during this period coupled with the increase in charcoal influx and fire episodes suggests that the early Holocene vegetation community was becoming increasingly more firedependent and vegetation was likely adapting to the increase in fire frequency associated with the period.

\section{Zone 3: 8000-3750 cal yr BP: middle Holocene}

Significant vegetation changes occur through the middle Holocene. From 8000 to $5500 \mathrm{cal} \mathrm{yr} \mathrm{BP,} \mathrm{C}_{4}$ Panicoideae (warm/wet) grasses were at the lowest values in the record. $\mathrm{C}_{3}$ Pooideae (cold/wet) grasses diminished after ca. $7000 \mathrm{cal}$ yr BP and remain absent for the remainder of the record. Arboreal phytoliths reached the highest levels in the record at $8000 \mathrm{cal} \mathrm{yr} \mathrm{BP}$, followed by a slight decline to $3500 \mathrm{cal}$ yr BP. $\delta^{13} \mathrm{C}$ values ranged between -24 and

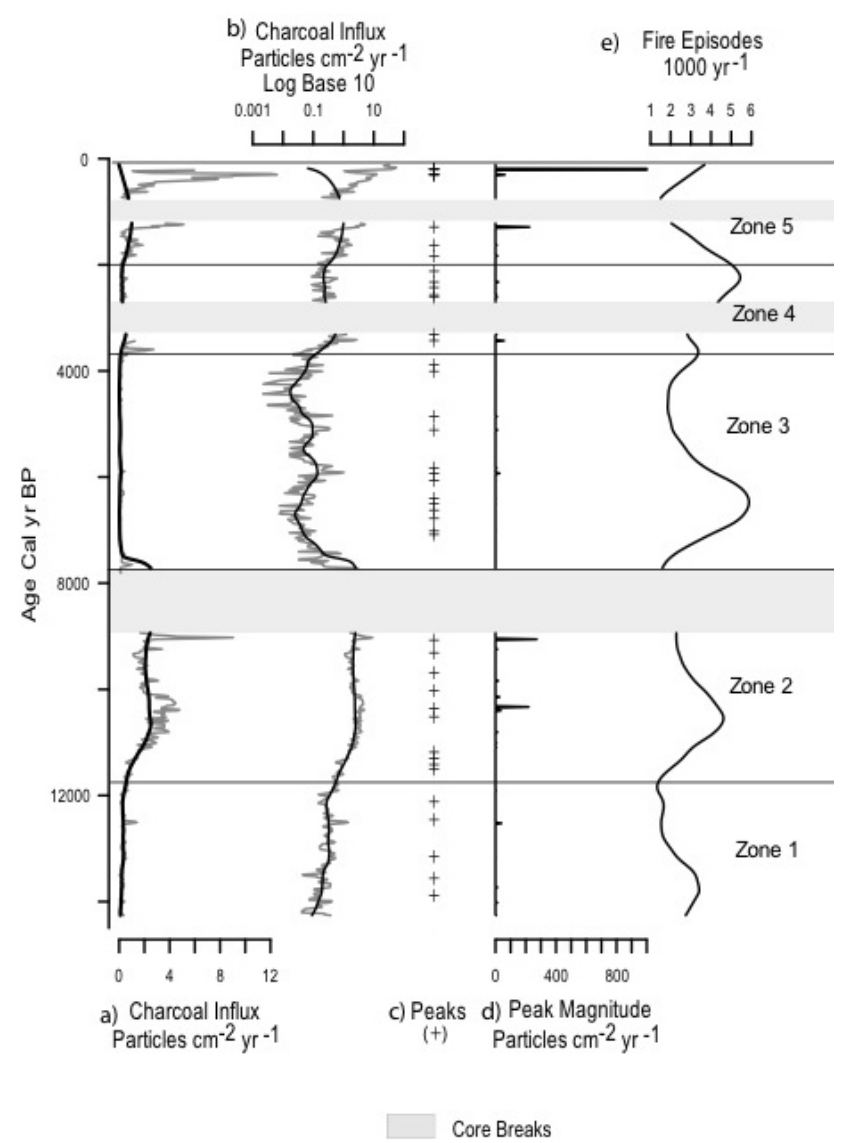

Figure 7. Huanchaca Mesetta charcoal data (a) charcoal influx in grey, black background; (b) charcoal influx log base 10 in grey, black background; (c) peaks indicated by crosses; (d) peak magnitude; and (e) fire episodes per 1000 years. Zones derived from phytolith data. Grey bars indicate core breaks.

$-22 \%$ from 7900 to 5100 cal yr BP. These values corresponded to a diminished $\mathrm{C}_{4}$ contribution to organic matter (approximately $18 \%$ ). Decreased $\mathrm{C}_{4}$ grass phytoliths from 8000 to 5000 cal yr BP was interpreted as a decrease in vegetation density in the open mesetta surrounding the basin caused by drying conditions on the mesetta. After 5000 cal yr BP, $\mathrm{C}_{4}$ Panicoideae grasses and $\mathrm{C}_{4}$ Chlorideae (warm/dry) grasses gradually increased in the surrounding watershed, coupled increased $\delta^{13} \mathrm{C}$ values to $-19 \%$. M. flexuosa phytoliths first appeared at $5000 \mathrm{cal} \mathrm{yr} \mathrm{BP}$, and gradually increased to modern levels by $3750 \mathrm{cal} \mathrm{yr} \mathrm{BP}$. The $\delta^{13} \mathrm{C}$ values decreased, potentially associated with the development of the $\mathrm{C}_{3} M$. flexuosa community. A dark-brown clay-sand mixture from 8000 to $3750 \mathrm{cal}$ yr BP dominated the lithology that transitioned to black detrital peat at ca. 3750 cal yr BP associated with the establishment of M. flexuosa. After 4000 cal yr BP, LOI, magnetic susceptibility, and $\mathrm{C}: \mathrm{N}$ values increased, indicating increased organic material. Nitrogen cycling continued to fluctuate throughout this period. $\delta^{15} \mathrm{~N}$ values exhibited the greatest frequency and ampli- 


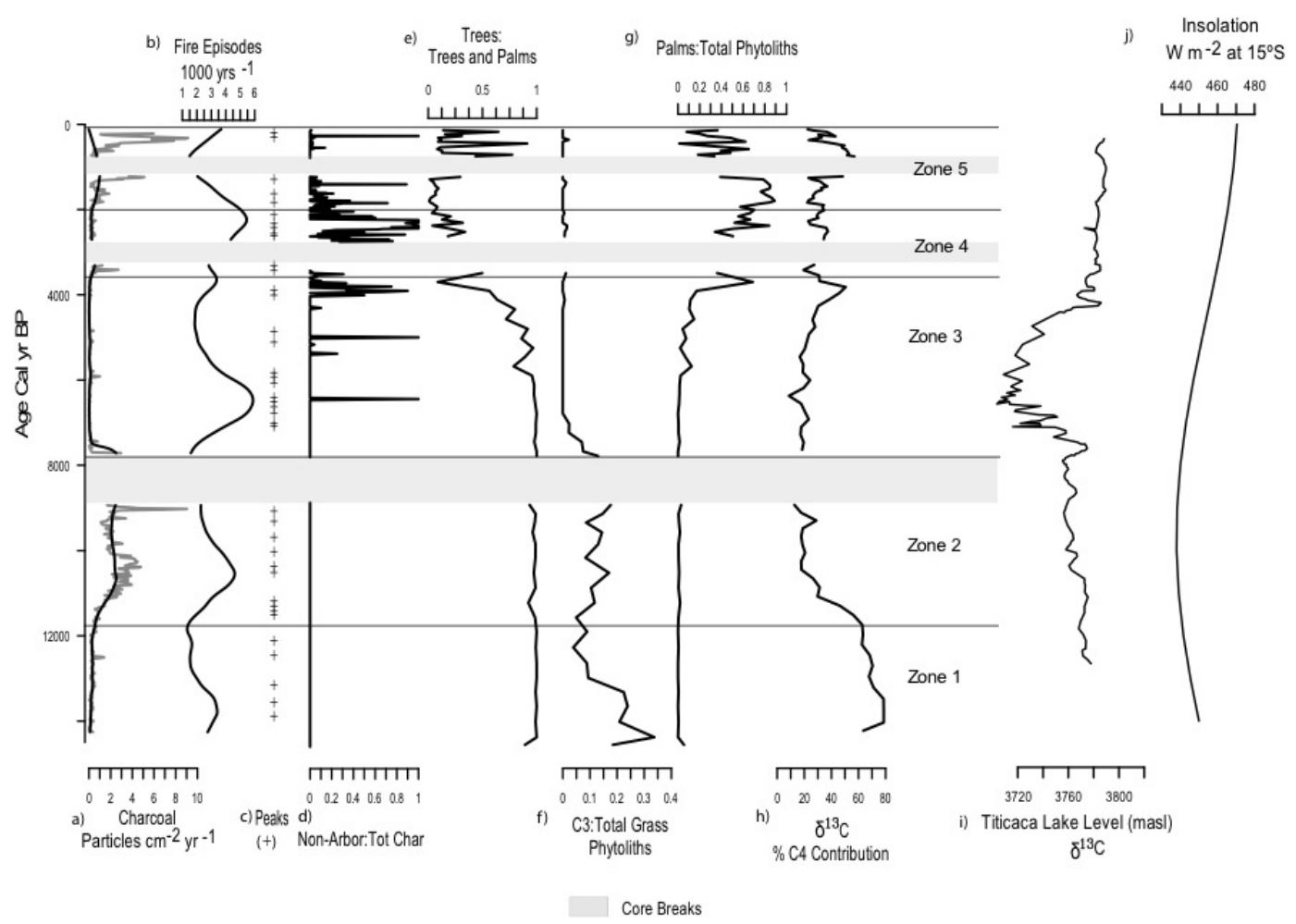

Figure 8. Huanchaca Mesetta summary: (a) charcoal influx in grey, black background; (b) fire episodes per 1000 years; (c) peaks indicated by crosses; (d) ratio of non-arboreal to total charcoal; (e) ratio of trees to trees and palms; (f) ratio of $\mathrm{C}_{3}$ to total grasses; (g) ratio of palms to total phytoliths; (h) \% $\mathrm{C}_{4}$ contribution; (i) lake level of Titicaca in $\mathrm{m}$ a.s.l.; and (j) insolation at $15^{\circ} \mathrm{S}$. Zones derived from phytolith data. Grey bars indicate core breaks.

tude of variability from 8000 to 3750 cal yr BP, ranging from 2 to $12 \%$, indicating repeated and extensive dry periods on the mesetta.

Increased charcoal influx at ca. 8000 cal yr BP was followed by an abrupt decrease to the lowest values during the record from ca. 7900 to ca. $3800 \mathrm{cal} \mathrm{yr} \mathrm{BP.} \mathrm{Peak} \mathrm{frequency}$ reached the highest levels of six fire episodes (periods of increased burning) per 1000 years during the middle Holocene. These data corresponded to the highest levels of $\delta^{15} \mathrm{~N}$ values, indicating extended dry periods that likely promoted frequent fires on the mesetta. The first evidence of grass charcoal appeared at ca. $6500 \mathrm{cal} \mathrm{yr} \mathrm{BP}$, suggesting a change in the fire ecology on the mesetta. From 5000 to 3750 cal year BP, grass charcoal increased. This is coincident with the establishment of $M$. flexuosa palm swamp and increased $\mathrm{C}_{4}$ grasses in the surrounding watershed. After $3900 \mathrm{cal} \mathrm{yr} \mathrm{BP,} \mathrm{charcoal} \mathrm{influx}$ and fire frequency increased. Significant increases in grass charcoal reflected a change in the fuel composition in the watershed. Phytolith, isotope, and charcoal data suggest that, after 3900 cal yr BP, the M. flexuosa within the basin became increasingly fire-sensitive and the occurrence of a fire within the palm stand would have had consequences for the vegetation not adapted to fire. The fire-adapted $\mathrm{C}_{4}$ grass-dominated watershed continued to be fire-dependent.
Zone 4: 3750 to 2000 cal yr BP: late Holocene

There is a decrease in arboreal taxa coupled with increased values of $M$. flexuosa. $\mathrm{C}_{4}$ Panicoideae (warm, wet) grasses continued to dominate the surrounding watershed. The lithology consisted of black detrital peat at ca. $2450-2050$ cal yr BP associated with high LOI values (ca. $22 \%$ organics) and magnetic susceptibility values (ca. $1000 \times 10^{-5}$ ). After $2500 \mathrm{cal}$ yr BP the $\% \mathrm{C}, \% \mathrm{~N}$, and $\delta^{15} \mathrm{~N}$ increased, suggesting moist, anoxic conditions that enabled moderate denitrification from the swamp. These lithologic and isotopic data represented the establishment of modern palm swamp characterized by increased autochthonous organic accumulation. The $\delta^{13} \mathrm{C}$ values reached modern levels by 2800 cal yr BP, although values exhibit increased variability co-varying with the $\mathrm{C}_{4}$ grass contribution.

Charcoal influx at Huanchaca Mesetta remained low 3750 to $2000 \mathrm{cal}$ yr BP with a FRI of five episodes (periods of increased burning) per 1000 years. Grass charcoal reached the highest continuous levels at ca. 2800 to 2000 cal yr BP, corresponding to high levels of fire-adapted $\mathrm{C}_{4}$ grass phytoliths. Increased grass charcoal coupled with low peak magnitude values and high fire frequency indicated that the vegetation surrounding the palm swamp was fire-dependent and fire- 
adapted. However, within the moist M. flexuosa palm stand, the vegetation remained fire-sensitive.

\section{Zone 5: 2000 cal yr BP to present: late Holocene}

M. flexuosa reached the highest levels in the record at ca. 1800 cal yr BP, followed by decreasing values towards the present. The presence of hat-shaped phytoliths at ca. 200 cal yr BP indicates very low concentrations of other palm species during this time. There was a gradual decrease in $M$. flexuosa towards the present coupled with the highest levels of $\mathrm{C}_{4}$ Panicoideae grasses at ca. $200 \mathrm{cal} \mathrm{yr} \mathrm{BP}$ and a decrease in $\mathrm{C}_{4}$ Chloridoideae (warm, dry) grasses in the surrounding watershed. The lithology was dominated by darkbrown detrital peat. After ca. $800 \mathrm{cal}$ yr BP $\delta^{13} \mathrm{C}$ values were ca. $-18 \%$ and the $\% \mathrm{C}_{4}$ contribution was ca. $50 \%$. These data corresponded to the highest levels of $\mathrm{C}_{4}$ Panicoideae grass phytoliths in the record. The dark detrital peat lithology was interrupted by two coarse sand layers at ca. 1550 and ca. 300-200 cal yr BP, followed by a shift back to black detrital peat from ca. $200 \mathrm{cal}$ yr BP to present. These sand layers were characterized by a decrease in LOI from ca. 22 to $2 \%$ organics, $\mathrm{C}: \mathrm{N}$ ratios from ca. 25 to 0 , and $\delta^{15} \mathrm{~N}$ from ca. 5 to $0 \%$ o coupled with increased magnetic susceptibility and bulk density values, suggesting clastic flood events associated with sandy sediments low in organic material. After $300 \mathrm{cal} \mathrm{yr} \mathrm{BP}, \% \mathrm{C}$ values increased from ca. $1 \%$ to $>20 \%$, reaching the highest values in the record. The $\% \mathrm{~N}$ values increased from ca. 0.2 to the peak Holocene values of 1.2 at present. The dramatic increases in both $\% \mathrm{C}$ and $\% \mathrm{~N}$ were likely the result of in situ carbon cycling and nitrogen fixation.

Charcoal influx increased after $2000 \mathrm{cal}$ yr BP at ca. 1400 to $1200 \mathrm{cal} \mathrm{yr} \mathrm{BP}$, and reached peak Holocene values at ca. 500-400 cal yr BP. Increased charcoal was coupled with the lowest FRI values in the record. Peak magnitude increased significantly around $1200 \mathrm{cal} \mathrm{yr} \mathrm{BP}$ and the largest peak magnitude values at ca. $200 \mathrm{cal}$ yr BP. These charcoal values were cropped for plotting and visualization purposes. Raw counts exceed 1200; thus the values are also provided logtransformed (Fig. 8). Peak frequency increased after ca. 400 cal yr BP to ca. 4 fire episodes (periods of increased burning) per 1000 years towards the present. There was a decrease in grass charcoal, indicating increased woody biomass burned. The increased charcoal influx coupled with low FRI and more woody charcoal was interpreted as being the result of fire episodes that infrequently penetrated the fire-sensitive palm stand and burned the M. flexuosa woody biomass. The charcoal, phytolith, and isotope data collectively suggest that the vegetation surrounding the palm swamp was firedependent and fire-adapted, while the vegetation within the palm swamp was fire-sensitive.

\section{Discussion}

\subsection{First-order control: edaphic constraints}

Modern vegetation distribution of cerrãdo savannas are largely related to edaphic factors (Colgan et al., 2012; Killeen, 1998a). Since the Lateglacial, the vegetation, soil geochemistry, and fire history indicate that edaphic constraints were the first order of control on vegetation on Huanchaca Mesetta. Despite significant climate variability since the Lateglacial (Baker et al., 2001; Cruz et al., 2005), the open savanna surrounding the basin was continuously dominated by fire-adapted $\mathrm{C}_{4}$ grasses. Within the basin, soil was sufficiently thick to support more complex vegetation communities that exhibited greater response to climate variability through time. On the highly weathered quartzite plateau, however, vegetation was limited to drought- and fire-tolerant $\mathrm{C}_{4}$ grasses, as indicated by the continued presence of $\mathrm{C}_{4}$ Panicoideae grass phytoliths that co-varied with the $\delta^{13} \mathrm{C}$ values.

The first hypothesis, that edaphic conditions are the dominant control of vegetation on the plateau, was supported based on phytolith and isotope data. Irrespective of changes in temperature, precipitation, and fire activity, savanna vegetation has been present on the mesetta for the past 14500 years. Edaphic conditions on the open rocky plateau have limited species composition to $\mathrm{C}_{4}$ drought-adapted grasses. Arboreal and palm vegetation was limited to the topographic depressions present on the plateau where soil was sufficiently deep to support more complex vegetation communities.

\subsection{Second-order control: climatological drivers}

\subsection{Lateglacial surazo winds and Mauritia flexuosa}

Non-analogue Lateglacial vegetation communities are documented from low-elevation sites including Laguna Chaplin $\left(14^{\circ} 28^{\prime} \mathrm{S}, 61^{\circ} 04^{\prime} \mathrm{W}\right.$; approximately $40 \mathrm{~km}$ west $)$ and Laguna Bella Vista $\left(13^{\circ}, 37^{\prime} \mathrm{S}, 61^{\circ}, 33^{\circ} \mathrm{W} ; 140 \mathrm{~km}\right.$ northwest of Huanchaca Mesetta). The absence of Anadenanthera, a key indicator in present-day deciduous and semi-deciduous dry forests, was interpreted as being the result of reduced precipitation (e.g., longer and/or more severe dry season), increased aridity, and lowered atmospheric $\mathrm{CO}_{2}$ concentrations. These conditions favored $\mathrm{C}_{4}$ grasses, sedges, and drought-adapted savanna and dry forest arboreal species (Burbridge et al., 2004). Similarly, the non-analogue Lateglacial vegetation community at Huanchaca Mesetta is notable for the absence of M. flexuosa. M. flexuosa can tolerate a broad precipitation gradient ranging from 1500 to $3500 \mathrm{~mm}$ annually in areas with annual temperature averages above $21^{\circ} \mathrm{C}$, roughly coinciding with the $1000 \mathrm{~m}$ a.s.l. contour line (Rull and Montoya, 2014). M. flexuosa is dependent on local hydrology, including water table depth and flooded conditions (Kahn, 1987). The presence of M. flexuosa in the lowland records at Laguna Chaplin and Laguna Bella Vista (ca. $200 \mathrm{~m}$ a.s.l.) during the Lateglacial (Burbridge et al., 2004) indicates that conditions 
were sufficiently warm with a locally wet habitat below the mesetta to support the palms despite an estimated $20 \%$ decrease in precipitation (Mayle et al., 2004; Punyasena, 2008). Temperature was thus likely a limiting factor for the establishment of $M$. flexuosa on the mesetta. However, temperature reconstructions of Lateglacial conditions from Laguna La Gaiba (ca. $500 \mathrm{~km}$ SE of Huanchaca Mesetta) indicate temperatures reached modern conditions (ca. 25 to $26.5^{\circ} \mathrm{C}$ ) around $19500 \mathrm{cal} \mathrm{yr} \mathrm{BP}$ and have remained relatively stable to present (Whitney et al., 2011). However, previous studies have suggested the increased frequency of surazo winds (Bush and Silman, 2004). An ice cap located on the Patagonian Andes generated an anomalously high pressure center in northwestern Patagonia, resulting in increased surazo cold fronts blowing cold, dry, southerly winds northward and penetrating the NKMNP region (Iriondo and Garcia, 1993; Latrubesse and Ramonell, 1994). The surazos may have been no more intense than those of present but likely occurred more often and lasted more of the year (Bush and Silman, 2004). Increased frequency of surazos would have had little effect on the absolute temperature minima, but the mean monthly and annual temperature minima may have been ca. $5{ }^{\circ} \mathrm{C}$ lower (Bush and Silman, 2004). Based on a lapse rate of $6.4^{\circ} \mathrm{C} \mathrm{km}^{-1}$ (Glickman, 2000), the $400 \mathrm{~m}$ difference between the lowland sites (Laguna Chaplin and Laguna Bella Vista, ca. $250 \mathrm{~m}$ a.s.l.) and Huanchaca Mesetta (ca. 650$800 \mathrm{~m}$ a.s.l.) could have resulted in up to ca. $2.6^{\circ} \mathrm{C}$ difference in average annual temperatures. Despite near-modern annual temperatures at ca. $19500 \mathrm{cal}$ yr BP, the elevational lapse rate coupled with lower mean monthly and annual temperature minima accompanying more frequent surazos likely resulted in climatic conditions below the thermal optimum of $21^{\circ} \mathrm{C}$ for M. flexuosa (Rull and Montoya, 2014). Thus, during the Lateglacial, increased frequency of surazos likely resulted in increased biological stress on the vegetation community at Huanchaca Mesetta, resulting in vegetation dominated by trees and grasses as opposed to M. flexuosa.

\subsubsection{Interpreting CharAnalysis in paleofire reconstructions at Huanchaca Mesetta}

The charcoal record from the Huanchaca Mesetta provides one of the first subcentennial paleofire records from the cerrãdo savanna ecosystem. Previous experimental studies on sedimentary charcoal from African savanna ecosystems support the use of sedimentary charcoal to reconstruct past fire activity in savanna systems (Aleman et al., 2013; Duffin et al., 2008). The Huanchaca Mesetta charcoal record presents a novel approach, combining charcoal influx data, CharAnalysis software (Higuera et al., 2007), and arboreal/non-arboreal charcoal ratios in Neotropical savanna ecosystems. Originally, CharAnalysis was designed as a peak-detection tool for forest ecosystems with low FRI in the Northern Hemisphere (Higuera et al., 2007). Paleoecological investigations in fire-prone systems such as savannas can be challenging because of the annual to multi-annual FRI complicating the identification of fire peaks and isolated fire events.

To address the challenge of reconstructing cerrãdo paleofire activity, charcoal influx was compared with the ratio of arboreal to non-arboreal grass charcoal to infer the primary fuel source during periods of elevated fire activity. Low charcoal influx values, coupled with low arboreal charcoal, were interpreted as periods of decreased burning. Increased charcoal influx values and/or increased arboreal charcoal that exceeded the background threshold were identified as fire episodes. Because of the temporal resolution of the record, fire episodes were not interpreted as isolated fires but rather as periods of time that experienced increased fire activity (indicated by higher FRI values). Thus, an increase in the FRI from 2 to 5 episodes per 1000 years, as seen from 8000 to $6000 \mathrm{cal} \mathrm{yr} \mathrm{BP}$, represents more than a $50 \%$ increase in the periods of burning over that 2000 -year period. These data indicate a substantial shift in paleofire activity during the middle Holocene, particularly as there were no significant changes in the vegetation record on the Huanchaca Mesetta during this time.

\subsubsection{Holocene precipitation, fuel moisture, and fuel availability}

During the middle Holocene in lowland Amazonia, the presence of dry forest taxa and increased charcoal influx at Laguna Chaplin and Laguna Bella Vista indicate a combination of seasonally flooded savannas and semideciduous dry forests (Mayle et al., 2004). At Laguna Orícore $\left(13^{\circ} 20^{\prime} 44.02^{\prime \prime} \mathrm{S}, 63^{\circ} 31^{\prime} 31.86^{\prime \prime} \mathrm{W} ; 335 \mathrm{~km}\right.$ northwest $)$, peaks in drought-tolerant arboreal taxa, coupled with maximum charcoal concentrations, indicate drier and regionally more open vegetation (Carson et al., 2014). Laguna Granja $\left(13^{\circ} 15^{\prime} 44^{\prime \prime} \mathrm{S}, 63^{\circ}, 42^{\prime} 37^{\prime \prime} \mathrm{W} ; 350 \mathrm{~km}\right.$ northwest) was also characterized by open savanna vegetation. These data suggest lower mean annual precipitation $(<150 \mathrm{~cm})$ and a longer dry season $(>5$ months with $<100 \mathrm{~cm}$ ) during the middle Holocene (Burbridge et al., 2004; Mayle et al., 2000). Additionally, water levels at Lake Titicaca were ca. $100 \mathrm{~m}$ below present (Fig. 8), attributed to precipitation levels ca. $40 \%$ below present (Baker et al., 2001; Cross et al., 2000; D'Agostino et al., 2002).

The discrepancy in increased fire activity in the lowland sites and decreased fire activity on the mesetta is attributed to fuel connectivity. In the lowland sites of Laguna Bella Vista, Laguna Chapin, and Laguna Orícore, dry forest-savanna vegetation provided sufficient fuel and increased fire activity during the middle Holocene. At Huanchaca Mesetta, decreased available moisture limited vegetation growth and fuel availability, particularly in the edaphically constrained rocky mesetta surrounding the basin. The lack of fine $\mathrm{C}_{4}$ grass connective fuels resulted in decreased burning on the mesetta.

Lake Titicaca reached modern water levels between 3750 cal yr BP and the present (Rowe et al., 2003), indi- 
cating wetter regional conditions with less severe dry seasons. The pollen assemblages of Laguna Bella Vista, Laguna Chaplin, and Laguna Orícore indicate an expansion of humid evergreen closed-canopy rainforest vegetation coupled with significant decreases in charcoal concentrations (Burbridge et al., 2004; Burn et al., 2010; Carson et al., 2014). The rainforest-savanna ecotone is currently at its most southerly extent in the Amazon Basin in at least the last 50000 years. (Mayle et al., 2000; Mayle and Whitney, 2012; Burbridge et al., 2004). The progressive succession through the Holocene in the lowlands of NKMNP from savanna/semi-deciduous forest to semi-deciduous/evergreen forest to evergreen rainforest is part of a long-term unidirectional trend of climatedriven rainforest expansion associated with the regional increase in precipitation associated with a stronger SASM (Mayle et al., 2004). The basin-wide increase in mean annual precipitation and reduction in the length/severity of the dry season is attributed to increasing summer insolation at $10-15^{\circ} \mathrm{S}$ driven by the Milankovitch precessional forcing (Mayle and Whitney, 2012). The wet conditions of the late Holocene created ideal waterlogged conditions for the establishment of the M. flexuosa palm swamp in the drainage basin.

During the late Holocene, the asynchrony of charcoal records between the low-elevation sites and Huanchaca Mesetta is attributed to fuel flammability. Increased precipitation led to different effects on fire frequency, with decreases in the lowlands and increases in Huanchaca Mesetta. Increased precipitation in the low-elevation closed-canopy rainforests decreased fuel flammability along with fire activity. Whereas increased precipitation resulted in the buildup of fire-adapted $\mathrm{C}_{4}$ grasses on the surrounding plateau. Lightning-caused fire is common in cerrãdo savannas today and highest in more open savanna ecosystems, such as the Huanchaca Mesetta (Ramos-Neto and Pivello, 2000). Increased precipitation would have been accompanied by increased incidence of lightning-caused fire, fueled by the abundance of fire-adapted grass fuels in the surrounding watershed.

The second hypothesis, that climate was the dominant control on savanna vegetation structure and floristic composition, was supported by the vegetation and fire data. Since the Lateglacial, climate change has coincided with both the vegetation composition and fire regimes on the plateau. The asynchrony in response to regional climate forcing at Huanchaca Mesetta and the low-elevation sites emphasizes the need to obtain more paleorecords across an elevational gradient to determine the effects of climate variability across heterogeneous ecosystems.

\subsection{Human versus natural drivers on the evolution of Mauritia flexuosa}

The development of M. flexuosa swamps and increases in charcoal influx have been seen in numerous paleoecologi- cal records from savanna ecosystems in Colombia (Behling and Hooghiemstra, 1998, 1999; Berrio et al., 2002a, b), Venezuela (Montoya et al., 2011b; Rull and Montoya, 2014; Rull, 1999, 2009), and Brazil (DaSilva Meneses et al., 2013). Previously two hypotheses have been proposed to account for the late Holocene development of these M. flexuosa palm swamps. The first hypothesis suggests that the increase in $M$. flexuosa and charcoal influx is attributed to increased precipitation and wet-season lightning fires driven by strengthened SASM activity (Kahn and de Castro, 1985; Kahn and de Granville, 1992; Kahn, 1987). The second hypothesis suggests that the simultaneous rise in M. flexuosa and charcoal was linked to intentional planting or semi-domestication of M. flexuosa for human use (Behling and Hooghiemstra, 1998, 1999; Montoya et al., 2011a; Rull and Montoya, 2014). Currently there is insufficient archeological evidence from any of these savanna sites to support a robust anthropogenic signal (Rull and Montoya, 2014). Previous paleoecological studies in the lowlands demonstrate humans were the dominant driver of local-scale forest-savanna ecotonal change in those areas (e.g., Bolivian Llanos de Moxos) dominated by complex earth-moving pre-Columbian cultures (Carson et al., 2014; Whitney et al., 2014). These studies suggest that even in areas with extensive geometric earthworks, inhabitants likely exploited naturally open savanna landscapes that they maintained around their settlement, rather than practicing labor-intensive deforestation of dense rainforest (Carson et al., 2014). Evidence for human occupation of the lowlands has been found with ceramics from soil pits in an interfluve ca. $25 \mathrm{~km}$ northwest of Laguna Chaplin and abundant ceramics and charcoal dating to ca. $470 \mathrm{cal}$ yr BP recovered from Anthosols (terra preta) throughout La Chonta ca. $150 \mathrm{~km}$ west of NKMNP (Burbridge et al., 2004). Implementing a new methodology to concentrate and isolate cultigen pollen (Whitney et al., 2012), the re-analysis of pollen data from Laguna Bella Vista and Laguna Chaplin revealed Zea mays pollen was present around 1000 to $400 \mathrm{cal} \mathrm{yr} \mathrm{BP;} \mathrm{approxi-}$ mately 2000 years after the initial increase in $M$. flexuosa at these sites (B. Whitney, personal communication, 2014). Although humans were present in NKMNP, there is no evidence that they drove regionally significant ecotonal changes in forest-savanna boundaries. The patterns of forest-savanna shifts exhibited at these sites are consistent with climate forcing (Burbridge et al., 2004). The absence of archeological data on Huanchaca Mesetta dominated by nutrient-poor, rocky soil, which would have been infertile for the practice of agriculture, coupled with the limited access to the mesetta would have made human habitation unlikely. Although the M. flexuosa swamps may have been used for hunting and gathering purposes, these data do not suggest humans were the driving mechanism behind the initial establishment or proliferation of M. flexuosa in the interfluvial depressions of the mesetta.

The comparison of the Huanchaca Mesetta record to previous studies coupled with the absence of archeological re- 
mains on the mesetta support the third hypothesis, that expansion of M. flexuosa at this site was largely controlled by natural drivers (edaphic, climate, lightning caused fires) as opposed to anthropogenic drivers. In contrast to the conclusions from other studies, this record provides no evidence for an anthropogenically driven fire regime, deforestation, soil erosion, or cultivation on the mesetta. These data suggest that natural drivers control the continued presence of savanna vegetation and fire activity on the Huanchaca Mesetta for the past 14500 years.

\section{Implications for savanna ecology and conservation}

The presence of savanna vegetation for the past 14500 years at Huanchaca Mesetta has significant implications for understanding modern savanna ecology and for the implementation of conservation strategies in the 21st century. Previous research on the evolution and development of savanna ecosystems has attributed much of the development of savannas to anthropogenic origins driven by the intentional use of fire (Arroyo-Kalin, 2012; Behling and Hooghiemstra, 1998, 1999; Behling, 2002; Berrio et al., 2002a; RamosNeto and Pivello, 2000; Rull and Montoya, 2014). The results from this study demonstrate that the continued presence of the savanna ecosystem at Huanchaca Mesetta is attributable to edaphic and climatic controls. The presence of fire in this system for the past 14500 years indicates that naturally occurring, lightning-caused fire is an integral part of the ecology of the savanna ecosystem. Despite changes in floristic composition and tree density within the drainage basin, the savanna ecosystem has been resilient to major climatic changes in both temperature and precipitation since the Lateglacial period. These data suggest that savanna ecosystems will continue to be resilient to future climate change associated with global warming. The long history of ecosystem stability in the face of dramatic climate variability attests to the fact that the Huanchaca Mesetta savanna is one of the most floristically diverse savannas anywhere in the Neotropics (DaSilva Meneses and Bates, 2002). The continued protection of the Huanchaca Mesetta savanna as a UNESCO world heritage site, coupled with the savanna's natural resilience to climatic change exhibited over at least the past 14500 years, indicates that, despite significant global warming projected for the 21st century (IPCC, 2014), there is good reason for optimism for the conservation and preservation of biological diversity in the Huanchaca Mesetta savanna ecosystem.

Acknowledgements. Funding to Y. Maezumi was provided by the Global Change and Sustainability Center, the Graduate Research Fellowship, the Don Currey Graduate Research Fellowship, and the PAGES Graduate Research Fellowship. We thank Mary McIntyre and Danie Harris for their help in sample prepara- tion and analysis. Jennifer Watling and the Archaeobotany Lab at the University of Exeter assisted in phytolith training. Lee Grismer provided support for this research. The University of Leicester provided funding to F. E. Mayle. We thank Tim Killeen and the Museo de Historia Natural "Noel Kempff Mercado", Santa Cruz, Bolivia, for providing logistical support, and in particular Rene Guillen and local guides (e.g., Juan Surubi) from the village of Florida for assistance with coring the site.

Edited by: D. Urrego

\section{References}

Abreu, M. F., Pinto, J. R. R., Maracahipes, L., Gomes, L., de Oliveira, E. A., Marimon, B. S., Junior, M., Hur, B., de Farias, J., and Lenza, E.: Influence of edaphic variables on the floristic composition and structure of the tree-shrub vegetation in typical and rocky outcrop cerrado areas in Serra Negra, Goiás State, Brazil, Braz. J. Bot., 35, 259-272, 2012.

Aleman, J. C., Blarquez, O., Bentaleb, I., Bonté, P., Brossier, B., Carcaillet, C., Gond, V., Gourlet-Fleury, S., Kpolita, A., and Lefèvre, I.: Tracking land-cover changes with sedimentary charcoal in the Afrotropics, Holocene, 23, 1853-1862, 2013.

Arroyo-Kalin, M.: Slash-burn-and-churn: Landscape history and crop cultivation in pre-Columbian Amazonia, Quat. Int., 249, 418, 2012.

Baker, P. A., Seltzer, G. O., Fritz, S. C., Dunbar, R. B., Grove, M. J., Tapia, P. M., Cross, S. L., Rowe, H. D., and Broda, J. P.: The history of South American tropical precipitation for the past 25000 years., Science, 291, 640-643, 2001.

Behling, H.: South and southeast Brazilian grasslands during Late Quaternary times: A synthesis, Palaeogeogr. Palaeoclimatol. Palaeoecol., 177, 19-27, 2002.

Behling, H. and Hooghiemstra, H.: Late Quaternary palaeoecology and palaeoclimatology from pollen records of the savannas of the Llanos Orientales in Colombia, Palaeogeogr. Palaeoclimatol. Palaeoecol., 139, 251-267, 1998.

Behling, H. and Hooghiemstra, H.: Environmental history of the Colombian savannas of the Llanos Orientales since the Last Glacial Maximum from lake records El Pinal and Carimagua, J. Paleolimnol., 21, 461-476, 1999.

Bennett, K. D.: Determination of the number of zones in a biostratigraphical sequence, New Phytol., 132, 155-170, 1996.

Berrio, J. C., Hooghiemstra, H., Behling, H., Botero, P., and Van der Borg, K.: Late-Quaternary savanna history of the Colombian Llanos Orientales from Lagunas Chenevo and Mozambique: A transect synthesis, Holocene, 12, 35-48, 2002a.

Berrio, J. C., Hooghiemstra, H., Marchant, R., and Rangel, O.: Lateglacial and Holocene history of the dry forest area in the south Colombian Cauca Valley, J. Quat. Sci., 17, 667-682, 2002b.

Bertoli de Pomar, H.: Ensayo de clasificacion morfologica de los silicofitolitos, Ameghiniana, 3, 317-328, 1971.

Blaauw, M.: Methods and code for "classical" age-modelling of radiocarbon sequences, Quat. Geochronol., 5, 512-518, 2010.

Brown, K. J. and Power, M. J.: Charred particle analyses., in The Encyclopedia of Quaternary Science, 716-729, Elsevier, Amsterdam, the Netherlands, 2013. 
Burbridge, R. E., Mayle, F. E. and Killeen, T. J.: Fifty-thousandyear vegetation and climate history of Noel Kempff Mercado National Park, Bolivian Amazon, Quat. Res., 61, 215-230, 2004.

Burn, M. J., Mayle, F. E., and Killeen, T. J.: Pollen-based differentiation of Amazonian rainforest communities and implications for lowland palaeoecology in tropical South America, Palaeogeogr. Palaeoclimatol. Palaeoecol., 295, 1-18, 2010.

Bush, M. B. and Silman, M. R.: Observations on Late Pleistocene cooling and precipitation in the lowland Neotropics, J. Quat. Sci., 19, 677-684, 2004.

Carson, J. F., Whitney, B. S., Mayle, F. E., Iriarte, J., Prümers, H., Soto, J. D., and Watling, J.: Environmental impact of geometric earthwork construction in pre-Columbian Amazonia., Proc. Natl. Acad. Sci. USA, 111, 1-6, 2014.

Codron, J., Codron, D., Lee-Thorp, J. A., Sponheimer, M., Bond, W. J., de Ruiter, D. and Grant, R.: Taxonomic, anatomical, and spatio-temporal variations in the stable carbon and nitrogen isotopic compositions of plants from an African savanna, J. Archaeol. Sci., 32, 1757-1772, 2005.

Colgan, M. S., Asner, G. P., Levick, S. R., Martin, R. E., and Chadwick, O. A.: Topo-edaphic controls over woody plant biomass in South African savannas, Biogeosciences, 9, 18091821, doi:10.5194/bg-9-1809-2012, 2012.

Cross, S. L., Baker, P. A., Seltzer, G. O., Fritz, S. C., and Dunbar, R. B.: A new estimate of the Holocene lowstand level of Lake Titicaca, central Andes, and implications for tropical palaeohydrology, Holocene, 10, 21-32, 2000.

Cruz, F. W., Burns, S. J., and Karmann, I.: Insolation-driven changes in atmospheric circulation over the past 116000 years in subtropical Brazil, Nature, 434, 63-66, 2005.

D'Agostino, K., Seltzer, G., Baker, P., Fritz, S., and Dunbar, R.: Late-Quaternary lowstands of Lake Titicaca: Evidence from high-resolution seismic data, Palaeogeogr. Palaeoclimatol. Palaeoecol., 179, 97-111, 2002.

DaSilva Meneses, J. M. C. and Bates, J. M.: Biogeographic patterns and conservation in the South American cerrado: A tropical savanna hotspot, Bioscience, 52, 225-234, 2002.

DaSilva Meneses, M. E. N., Da Costa, M. L., and Behling, H.: Late Holocene vegetation and fire dynamics from a savanna-forest ecotone in Roraima state, northern Brazilian Amazon, J. South Am. Earth Sci., 42, 17-26, 2013.

Dean Jr, W. E.: Determination of carbonate and organic matter in calcareous sediments and sedimentary rocks by loss on ignition: Comparison with other methods, J. Sediment. Res., 44, 242-248, 1974.

Duffin, K. I., Gillson, L., and Willis, K. J.: Testing the sensitivity of charcoal as an indicator of fire events in savanna environments: quantitative predictions of fire proximity, area and intensity, Holocene, 2, 279-291, 2008.

Fidelis, A. T., Delgado Cartay, M. D., Blanco, C. C., Muller, S. C., Pillar, V. de P., and Pfadenhauer, J. S.: Fire intensity and severity in Brazilian Campos grasslands, Interciencia Rev. Cienc. y Tecnol. Am., 35, 739-745, 2010.

Fredlund, G. G. and Tieszen, L. T.: Modern phytolith assemblages from the North American Great Plains, J. Biogeogr., 21, 321335, 1994.

Furley, P. A. and Ratter, J. A.: Soil resources and plant communities of the central Brazilian cerrado and their development, J. Biogeogr., 15, 97-108, 1988.
Gedye, S. J., Jones, R. T., Tinner, W., Ammann, B., and Oldfield, F.: The use of mineral magnetism in the reconstruction of fire history: A case study from Lago di Origlio, Swiss Alps, Palaeogeogr. Palaeoclimatol. Palaeoecol., 164, 101-110, 2000.

Glickman, T. S.: Glossary of meteorology, 2nd ed., American Meteorological Society, Boston, MA., USA, 885 pp., 2000.

Grimm, E. C.: CONISS: A Fortran 77 program for stratigraphically constrained cluster analysis by the method of the incremental sum of squares, Comput. Geosci., 13, 13-35, 1987.

Hanagarth, W.: Acerca de la geoecología de las sabanas del Beni en el noreste de Bolivia, Instituto de Ecología, La Paz, Bolivia, 1993.

Hardesty, J., Myers, R., and Fulks, W.: Fire, ecosystems, and people: A preliminary assessment of fire as a global conservation issue, George Wright Forum, 22, 78-87, 2005.

Haridasan, M.: Nutrição mineral de plantas nativas do cerrado, Rev. Bras. Fisiol. Veg., 12, 54-64, 2000.

Hartley, W.: Studies on the origin, evolution, and distribution of the Gramineae. I. The tribe Andropogoneae, Aust. J. Bot., 6, 115128, 1958a.

Hartley, W.: Studies on the origin, evolution, and distribution of the Gramineae. II. The Tribe Paniceae, Aust. J. Bot., 6, 343-357, $1958 b$.

Hartley, W.: Studies on the origin, evolution, and distribution of the Gramineae. IV. The genus Poa L., Aust. J. Bot. Ecol., 9, 152-161, 1961.

Hartley, W.: Studies on the origin, evolution, and distribution of the Gramineae. V. The subfamily Festucoideae., Aust. J. Bot., 21, 201-234, 1973.

Hartley, W. and Slater, C.: Studies on the origin, evolution, and distribution of the Gramineae. III. The tribes of the subfamily Eragrostoideae, Aust. J. Bot., 8, 256-276, 1960.

Higuera, P. E., Brubaker, L. B., Anderson, P. M., Feng, S. H., and Brown, Thomas, A.: Vegetation mediated the impacts of postglacial climate change on fire regimes in the south-central Brooks Range, Alaska, Ecol. Monogr., 79, 201-219, 2009.

Higuera, P., Peters, M., Brubaker, L., and Gavin, D.: Understanding the origin and analysis of sediment-charcoal records with a simulation model, Quat. Sci. Rev., 26, 1790-1809, 2007.

Huber, O.: Geographical and physical features, in Flora of the Venezuelan Guayana, edited by: Berry, P. E., Holst, B. K., and Yatskievych, K., 1-62, Missouri Botanical Garden, St. Louis, MO, USA, 1995a.

Huber, O.: Vegetation, in Flora of the Venezuelan Guayana, edited by: Berry, P. E., Holst, B. K., and Yatskievych, K., 97-160, Missouri Botanical Garden, St. Louis, MO, USA, 1995 b.

IPCC, 2014: Climate Change 2014: Impacts, adaptation, and vulnerability. Part A: Global and sectoral aspects, Cambridge University Press, Cambridge, UK, 2014.

Iriarte, J.: Assessing the feasibility of identifying maize through the analysis of cross-shaped size and three-dimensional morphology of phytoliths in the grasslands of southeastern South America, J. Archaeol. Sci., 30, 1085-1094, 2003.

Iriarte, J.: Vegetation and climate change since 14810 14C yr B.P. in southeastern Uruguay and implications for the rise of early Formative societies, Quat. Res., 65, 20-32, 2006.

Iriarte, J. and Paz, E. A.: Phytolith analysis of selected native plants and modern soils from southeastern Uruguay and its implications 
for paleoenvironmental and archeological reconstruction, Quat. Int., 193, 99-123, 2009.

Iriondo, M. and Garcia, N.: Climatic variations in the Argentine plains during the last 18000 years, Palaeogeogr. Palaeoclimatol. Palaeoecol., 101, 209-220, 1993.

Jensen, K., Lynch, E. A., Calcote, R., and Hotchkiss, S. C.: Interpretation of charcoal morphotypes in sediments from Ferry Lake, Wisconsin, USA: Do different plant fuel sources produce distinctive charcoal morphotypes?, Holocene, 17, 907-915, 2007.

Junior, B. H. M. and Haridasan, M.: Comparação da vegetação arbórea e características edáficas de um cerradão e um cerrado sensu strictoem áreas adjacentes sobre solo distrófico no leste de Mato Grosso, Brasil, Acta Bot. Brasilica, 19, 913-926, 2005.

Kahn, F.: The distribution of palms as a function of local topography in Amazonian terra-firme forests, Cell. Mol. Life Sci., 43, 251259, 1987.

Kahn, F.: Ecology of economically important palms in Peruvian Amazonia, Adv. Econ. Bot., 6, 42-49, 1988.

Kahn, F. and de Castro, A.: The palm community in a forest of central Amazonia, Brazil, Biotropica, 1, 210-216, 1985.

Kahn, F. and de Granville, J. J.: Palms in forest ecosystmes of Amazonia ecological studies, 98, Springer-Verlag, Heidelberg, Germany, 1992.

Killeen, T. J.: The grasses of Chiquitanía, Santa Cruz, Bolivia, Ann. Missouri Bot. Gard., 1, 125-201, 1990.

Killeen, T. J.: Geomorphology of the Huanchaca Plateau and surrounding areas, in A biological assessment of Parque Nacional Noel Kempff Mercado, Bolivia, edited by: Killeen, T. J. and Schulenberg, T. S., 43-46, Conservation International, Washington, DC., 1998a.

Killeen, T. J.: Vegetation and flora of Parque Nacional Noel Kempff Mercado, in: A biological assessment of Parque Nacional Noel Kempff Mercado, Bolivia, edited by: Killeen, T. J. and Schulenberg, T. S., 61-85, Conservation International, Washington, USA, 1998b.

Killeen, T. J. and Schulenberg, T. S.: Vegetation and flora of Noel Kempff Mercado National Park. A biological assessment of Parque Nacional Noel Kempff Mercado, Bolivia, RAP working papers 10, Conservation International, Washington, USA, 1998.

Killeen, T. J., Siles, T. M., Grimwood, T., Tieszen, L. L., Steininger, M. K., Tucker, C. J., and Panfil, S.: Habitat heterogeneity on a forest-savanna ecotone in Noel Kempff Mercado National Park (Santa Cruz, Bolivia): Implications for the long-term conservation of biodiversity in a changing climate, in: How Landscapes Change, vol. 162, edited by: Bradshaw, G. and Marquet, P., 285312, Springer Verlag, Berlin, 2003.

Latrubesse, E. M. and Ramonell, C. G.: A climatic model for southwestern Amazonia in last glacial times, Quat. Int., 21, 163-169, 1994.

Latrubesse, E. M., Stevaux, J. C., Cremon, E. H., May, J.-H., Tatumi, S. H., Hurtado, M. A., Bezada, M., and Argollo, J. B.: Late Quaternary megafans, fans and fluvio-aeolian interactions in the Bolivian Chaco, Tropical South America, Palaeogeogr. Palaeoclimatol. Palaeoecol., 356, 75-88, 2012.

Litherland, M. and Power, G.: The geologic and geomorphic evolution of Serrania Huanchaca (Eastern Bolivia): The lost world, J. South Am. Earth Sci., 2, 1-17, 1989.

Malamud-Roam, F. P., Ingram, L. B., Hughes, M., and Florsheim, J. L.: Holocene paleoclimate records from a large California estuar- ine system and its watershed region: Linking watershed climate and bay conditions, Quat. Sci. Rev., 25, 1570-1598, 2006.

Malhi, Y., Meir, P., and Brown, S.: Forests, carbon and global climate, Philos. Trans. R. Soc. London, 360, 1567-1591, 2002.

Marlon, J. R., Bartlein, P. J., Carcaillet, C., Gavin, D. G., Harrison, S. P., Higuera, P. E., Joos, F., Power, M. J. and Prentice, I. C.: Climate and human influences on global biomass burning over the past two millennia, Nat. Geosci., 1, 697-702, 2008.

Marlon, J. R., Bartlein, P. J., Daniau, A., Harrison, S. P., Maezumi, S. Y., Power, M. J., Tinner, W., and Vanniére, B.: Global biomass burning: A synthesis and review of Holocene paleofire records and their controls, Quat. Sci. Rev., 65, 5-25, 2013.

Mayle, F. E., Beerling, D. J., Gosling, W. D., and Bush, M. B.: Responses of Amazonian ecosystems to climatic and atmospheric carbon dioxide changes since the last glacial maximum., Philos. Trans. R. Soc. B, 359, 499-514, 2004.

Mayle, F. E., Burbridge, R., and Killeen, T. J.: Millennial-scale dynamics of southern Amazonian rain forests, Science, 290, 22912294, 2000.

Mayle, F. E., Langstroth, R. P., Fisher, R. A., and Meir, P.: Longterm forest-savannah dynamics in the Bolivian Amazon: Implications for conservation., Philos. Trans. R. Soc. B., 362, 291-307, 2007.

Mayle, F. E. and Whitney, B. S.: Long-term perspectives on tropical forest-savanna dynamics in lowland Bolivia from the last ice age until present, in: Ecotones Between Forest and Grassland, edited by: Myster, R. W., 189-207, Springer, London, UK, 2012.

McCormac, F. G., Hogg, A. G., Blackwell, P. G., Buck, C. E., Higham, T. F. G., and Reimer, P. J.: SHCAL04 southern hemisphere calibration, 0-11.0 cal KYR BP, Radiocarbon, 46, 10871092, 2004.

McLauchlan, K. K., Lascu, I., Myrbo, A., and Leavitt, P. R.: Variable ecosystem response to climate change during the Holocene in northern Minnesota, USA, Geol. Soc. Am. Bull., 23, 16351643, 2013.

Miranda, H. S., Sato, M. N., Neto, W. N., and Aires, F. S.: Fires in the Cerrado, the Brazilian savanna, in: Tropical Fire Ecology: Climate change, land use and ecosystem dynamics, edited by: Cochrane, M. A., 427-450, Springer, Berlin, Germany, 2009.

Mistry, J.: Fire in the Cerrado (savannas) of Brazil: An ecological review, Prog. Phys. Geogr., 22, 425-448, 1998.

Mittermeier, R. A., Myers, N., Mittermeier, C. G., and Robles Gil, P.: Hotspots: Earth's biologically richest and most endangered terrestrial ecoregions, CEMEX, SA, Agrupación Sierra Madre, Mexico, 1999.

Montes de Oca, I.: Geografía y recursos naturales de Bolivia, 3rd Ed., Edobol, La Paz, Bolivia, 1982.

Montoya, E. and Rull, V.: Gran Sabana fires (SE Venezuela): a paleoecological perspective, Quat. Sci. Rev., 30, 3430-3444, 2011.

Montoya, E., Rull, V., and Nogué, S.: Early human occupation and land use changes near the boundary of the Orinoco and the Amazon basins (SE Venezuela): Palynological evidence from El Paují record, Palaeogeogr. Palaeoclimatol. Palaeoecol., 310, 413-426, $2011 \mathrm{a}$.

Montoya, E., Rull, V., Stansell, N. D., Abbott, M. B., Nogué, S., Bird, B. W., and Díaz, W. A.: Forest - savanna - morichal dynamics in relation to fire and human occupation in the southern Gran Sabana (SE Venezuela) during the last millennia, Quat. Res., 76, 335-344, 2011 b. 
Mueller, J. R., Long, C. J., Williams, J. J., Nurse, A., and McLauchlan, K. K.: The relative controls on forest fires and fuel source fluctuations in the Holocene deciduous forests of southern Wisconsin, USA, J. Quat. Sci., 29, 561-569, 2014.

Myers, N., Mittermeier, R. A., Mittermeier, C. G., Da Fonseca, G. A., and Kent, J.: Biodiversity hotspots for conservation priorities., Nature, 403, 853-858, 2000.

Nowaczyk, N. R.: Logging of magnetic susceptibility, in: Tracking environmental change using lake sediments, 155-170, Springer, the Netherlands, Potsdam, Germany, 2001.

Perdue, E. M. and Koprivnjak, J.-F.: Using the C/N ratio to estimate terrigenous inputs of organic matter to aquatic environments, Estuar. Coast. Shelf Sci., 73, 65-72, 2007.

Pereira, J. M. C.: Remote sensing of burned areas in tropical savannas, Int. J. Wildl. Fire, 12, 259-270, 2003.

Piperno, D. R.: Phytoliths and microscopic charcoal from leg 155: A vegetational and fire history of the Amazon Basin during the last 75 Ky, Proc. Ocean Drill. Progr., 155, 411-418, 1997.

Piperno, D. R.: Phytoliths: A comprehensive guide for archaeologists and paleoecologists, Altamira Press, Oxford, UK, 2005.

Piperno, D. R. and Pearsall, D. M.: The silica bodies of tropical American grasses: Morphology, taxomony, and implication from grass systematics and fossil phytolith identification, Smithsonian Institution Press, Washington, USA, 1998.

Pivello, V. R.: The use of fire in the Cerrado and Amazonian rainforests of Brazil: Past and present, Fire Ecol., 7, 24-39, 2011.

Punyasena, S. W.: Estimating neotropical palaeotemperature and palaeoprecipitation using plant family climatic optima, Palaeogeogr. Palaeoclimatol. Palaeoecol., 265, 226-237, 2008.

Ramos-Neto, M. B. and Pivello, V. R.: Lightning fires in a Brazilian savanna National Park: Rethinking management strategies, Environ. Manage., 26, 675-684, 2000.

Reimer, P. J., Bard, E., Bayliss, A., Beck, J. W., Blackwell, P. G., Bronk Ramsey, C., Buck, C. E., Cheng, H., Edwards, R. L., and Friedrich, M.: IntCal13 and Marine13 radiocarbon age calibration curves $0-50,000$ years cal BP, Radiocarbon, 55, 1869-1887, 2013.

Reynolds, R., Belnap, J., Reheis, M., Lamothe, P., and Luiszer, F.: Aeolian dust in Colorado Plateau soils: Nutrient inputs and recent change in source, Proc. Natl. Acad. Sci., 98, 7123-7127, 2001.

Ribeiro, J. F. and Walter, B. M. T.: As principais fitofisionomias do Bioma Cerrado, in Cerrado: Ecologia e flora, 151-212, EmbrapaCPAC, Planaltina, Brazil, 2008.

Robinson, D.: Roots and resources fluxes in plant and communities, Blackwell Scientific Publications, Oxford, UK, 1991.

Roche, M. A. and Rocha, N.: Precipitacioes anuales. Programa climatólogico e hidrológico de la Cuenca Amazónica Boliviana (PHICAB), Servicio Nacional de Meteologia e Hidrologia (SENAHMHI), La Paz, Bolivia, 1985.

Rowe, H. D., Guilderson, T. P., Dunbar, R. B., Southon, J. R., Seltzer, G. O., Mucciarone, D. A., Fritz, S. C., and Baker, P. A.: Late Quaternary lake-level changes constrained by radiocarbon and stable isotope studies on sediment cores from Lake Titicaca, South America, Glob. Planet. Change, 38, 273-290, 2003.

Rull, V.: A palynological record of a secondary succession after fire in the Gran Sabana, Venezuela, J. Quat. Sci., 14, 137-152, 1999.
Rull, V.: On the use of paleoecological evidence to assess the role of humans in the origin of the Gran Sabana (Venezuela), Hum. Ecol., 37, 783-785, 2009.

Rull, V. and Montoya, E.: Mauritia flexuosa palm swamp communities: Natural or human-made? A palynological study of the Gran Sabana region (northern South America) within a neotropical context, Quat. Sci. Rev., 99, 17-33, 2014.

Russell-Smith, J., Lucas, D., Gapindi, M., Kapirigi, N., Namingum, G., Giuliani, P., and Chaloupka, G.: Aboriginal resource utilization and fire management practice in western Arnherm land, monsoonal northern Australia: Notes for prehistory, lessons for the future, Hum. Ecol., 25, 159-195, 1997.

Seitzinger, S., Harrison, J. A., Böhlke, J. K., Bouwman, A. F., Lowrance, R., Peterson, B., Tobias, C., and Van Drecht, G.: Denitrification across landscapes and waterscapes: A synthesis, Ecol. Appl., 16, 2064-2090, 2006.

Sendulsky, T. and Labouriau, L. G.: Corpos siliceos de Gramineas dos Cerrados-I, Annais da Acad. Bras. Ciencias, 38, 159-185, 1966.

Söndahl, M. R.-I. and Labouriau, L. G.: Corpos silicosos de gramíneas dos Cerrados. IV, Pesqui. Agropecuária Bras., 5, 183 207, 1970.

Teixeira da Silva, S. and Labouriau, L. G.: Corpos siliceos de gramineas dos Cerrados-III, Pesqui. Agropecu. Bras., 5, 167$182,1970$.

Tweiten, M. A., Hotchkiss, S. C., Booth, R. K., Calcote, R. R., and Lynch, E. A.: The response of a jack pine forest to late-Holocene climate variability in northwestern Wisconsin, Holocene, 19, 1049-1061, 2009.

Twiss, P. C., Suess, E., and Smith, R. M.: Morphological classifocation of grass phytoliths, Proc. Soil Sci. Am., 33, 109-115, 1969.

van der Werf, G. R., Randerson, J. T., Giglio, L., Collatz, G. J., Mu, M., Kasibhatla, P. S., Morton, D. C., DeFries, R. S., Jin, Y., and van Leeuwen, T. T.: Global fire emissions and the contribution of deforestation, savanna, forest, agricultural, and peat fires (19972009), Atmos. Chem. Phys., 10, 11707-11735, doi:10.5194/acp10-11707-2010, 2010.

Vuille, M., Burns, S. J., Taylor, B. L., Cruz, F. W., Bird, B. W., Abbott, M. B., Kanner, L. C., Cheng, H., and Novello, V. F.: A review of the South American monsoon history as recorded in stable isotopic proxies over the past two millennia, Clim. Past, 8, 1309-1321, doi:10.5194/cp-8-1309-2012, 2012.

Whitlock, C. and Larsen, C.: Charcoal as a fire proxy, in Tracking environmental change using lake sediments, pp. 75-97, Kluwer Academic Publishers, Dordrecht, the Netherlands, 2001.

Whitney, B. S., Dickau, R., Mayle, F. E., Walker, J. H., Soto, J. D., and Iriarte, J.: Pre-Columbian raised-field agriculture and land use in the Bolivian Amazon, Holocene, 24, 231-241, 2014.

Whitney, B. S., Mayle, F. E., Punyasena, S. W., Fitzpatrick, K. A., Burn, M. J., Guillen, R., Chavez, E., Mann, D., Pennington, R. T., and Metcalfe, S. E.: A 45kyr palaeoclimate record from the lowland interior of tropical South America, Palaeogeogr. Palaeoclimatol. Palaeoecol., 307, 177-192, 2011.

Whitney, B. S., Rushton, E. A., Carson, J. F., Iriarte, J., and Mayle, F. E.: An improved methodology for the recovery of Zea mays and other large crop pollen, with implications for environmental archaeology in the Neotropics, Holocene, 22, 1087-1096, 2012.

Willis, K. J., Araújo, M. B., Bennett, K. D., Figueroa-Rangel, B., Froyd, C. A., and Myers, N.: How can a knowledge of the past 
help to conserve the future? Biodiversity conservation and the relevance of long-term ecological studies., Philos. Trans. R. Soc. B, 362, 175-86, 2007.

Zucol, A. F.: Microfitolitos de las Poaceae Argentinas: I. Microfitolitos foliares de algunas especies del genero Stipa (Stipae: Arundinoideae), de la Provincia de Entre Rios, Darwiniana, 34, 151-172, 1996.

Zucol, A. F.: Microfitolitos de las Poaceae Argentinas: II. Microfitolitos foliares de algunas especies del genero Panicum (Poaceae, Paniceae) de la Provincia de Entre Rios, Darwiniana, 36, 29-50, 1998.
Zucol, A. F.: Fitolitos de las Poaceae Argentinas: IV. Asociación Fitolítica de Cortaderia Selloana (Danthonieae: Poaceae), de la Provincia de Entre Ríos (Argentina), Nat. Neotrop., 1, 25-33, 1999.

Zucol, A. F.: Fitolitos de Poaceae de Argentina. III. Fitolitos foliares de especies del género Paspalum (Paniceae) en la provincia de Entre Ríos, Darwiniana, nueva Ser., 38, 11-32, 2000. 